Volume 63

\title{
Fear and Loathing: Shame, Shaming, and Intellectual Property
}

Elizabeth L. Rosenblatt

Follow this and additional works at: https://via.library.depaul.edu/law-review

\section{Recommended Citation}

Elizabeth L. Rosenblatt, Fear and Loathing: Shame, Shaming, and Intellectual Property, 63 DePaul L. Rev. 1 (2013)

Available at: https://via.library.depaul.edu/law-review/vol63/iss1/2

This Article is brought to you for free and open access by the College of Law at Digital Commons@DePaul. It has been accepted for inclusion in DePaul Law Review by an authorized editor of Digital Commons@DePaul. For more information, please contact digitalservices@depaul.edu. 


\title{
FEAR AND LOATHING: SHAME, SHAMING, AND INTELLECTUAL PROPERTY
}

\author{
Elizabeth L. Rosenblatt*
}

\section{INTRODUCTION}

Shame is civilizing. It is the governing drive of conscience; if people had no shame, the rule of law would lose much of its power, and might would often mean right. Shaming-the public attempt to impose shame on others-is an equally important driver of behavior. People strive to avoid humiliation and the loss of reputation; we steer clear of "bad" behaviors even if they would benefit us. In the words of Seneca the Younger, "Shame can forbid sometimes what the law does not." 1

Shame and shaming are crucial to our understanding of intellectual property law and norms, and yet they have gone largely unexplored in the intellectual property literature. Many scholars have examined intellectual property norms and how they interact with the law. ${ }^{2}$ But it is not enough to point out that someone acts a certain way because of norms; we must also understand the motivational forces that drive people to conform. In the criminal and tax law contexts, scholars have paid ample attention to the role of shame and shaming in governing

* Assistant Professor and Director, Whittier Law School Center for Intellectual Property Law. For their insights and input, I would like to thank Annemarie Bridy; Chris Buccafusco; Adam Candeub; Stewart Chang; Eric Goldman; Leah Chan Grinvald; Cynthia Ho; Eric E. Johnson; Edward Lee; Manoj Mate; Dotan Oliar; Lisa Ramsay; Al and Julie Rosenblatt; Wendy Rosenstein; Chris Sprigman; Ethan Zuckerman; the participants at the 2012 Intellectual Property Scholars' Conference; the participants at the 2013 Chicago IP Colloquium; and the participants at the 2013 WIPIP Conference.

1. Lucius Annaeus Seneca, Trojan Women (Troades), reprinted in 1 Seneca: The Tragedies 1, 14 (David R. Slavitt \& Palmer Bovie eds., 1992).

2. Much of this literature discusses norms as they relate to fields outside the scope of formal intellectual property. See infra notes 4-19 and sources cited therein. Another strand explores the relationship between norms and existing formal law. See, e.g., Jennifer E. Rothman, The Questionable Use of Custom in Intellectual Property, 93 VA. L. Rev. 1899, 1905-06 (2007) (discussing influence of norms on scope of IP rights); Sean B. Seymore, Rethinking Novelty in Patent Law, 60 Duke L.J. 919, 929 (2011) (referencing a "disconnect between patent law and the norms of science"); John Tehranian, Infringement Nation: Copyright Reform and the Law/Norm Gap, 2007 Utah L. Rev. 537, 543-50 (discussing disparity between copyright law and norms of infringement). See generally Christopher Jensen, Note, The More Things Change, The More They Stay the Same: Copyright, Digital Technology, and Social Norms, 56 Stan. L. Rev. 531 (2003) (discussing attempts to create a link between digital copyright law and social norms surrounding tangible property rights). 
behavior and, particularly, in reinforcing formal law. ${ }^{3}$ Yet few have recognized what major roles shame and shaming play in the way people choose to follow or disregard intellectual property law.

In the shadow of formal law, shame and shaming govern intellectual property's liminal spaces, where protection is uncertain or inconsistent with the strictures of formal law. Much intellectual creation occurs in markets, where selfish needs and wants must control. There is no Utopian commons where the fruits of creation and innovation are shared by all; pride and practicality demand some measure of ownership or control, tempting creators and copiers to claim more than they have made. Shame and shaming temper these impulses. They reflect the needs and wants of individual creative communities and, based on those needs, either restrict copying or promote it. Where formal law does not reach, shame and shaming create and facilitate copying norms, imposing order and predictability. Where the law does reach, shame and shaming provide a release valve: the discourse of shame surrounding over-assertions of rights encourages rights holders to forbear from asserting weak or overreaching claims rather than being publicly identified as "bullies" or "trolls." Thus, together, shame and shaming help to create and maintain "low-IP equilibria," 4 where copying norms are created and internalized by the creative community and optimized to its needs, rather than being imposed, top-down, by Congress and courts.

The result is an overlay of shame- and shaming-driven behavior that sits atop, and informally adjusts the boundaries of, formal intellectual property protection. This dynamic establishes and enforces intellectual property "negative spaces"-areas where innovation and creation thrive without significant formal intellectual property protection or enforcement. ${ }^{5}$ A number of scholars have explored intellectual prop-

3. See generally, e.g., Dan M. Kahan, Reciprocity, Collective Action, and Community Policing, 90 Calif. L. Rev. 1513, 1536 (2002) [hereinafter Kahan, Reciprocity]; Dan M. Kahan, What do Alternative Sanctions Mean?, 63 U. CHI. L. Rev. 591 (1996) [hereinafter Kahan, Alternative Sanctions]; Toni M. Massaro, Shame, Culture, and American Criminal Law, 89 Mich. L. Rev. 1880 (1991); Eric A. Posner, Law and Social Norms: The Case of Tax Compliance, 86 VA. L. Rev. 1781 (2000); Richard A. Posner \& Eric B. Rasmusen, Creating and Enforcing Norms, with Special Reference to Sanctions, 19 Int'L Rev. L. \& Econ. 369 (1999); Raffaele Rodogno, Shame, Guilt, and Punishment, 28 LAw \& PhiL. 429 (2009); James Q. Whitman, What Is Wrong with Inflicting Shame Sanctions?, 107 Y ALE L.J. 1055 (1998); Note, Shame, Stigma, and Crime: Evaluating the Efficacy of Shaming Sanctions in Criminal Law, 116 Harv. L. Rev. 2186 (2003).

4. See Kal Raustiala \& Christopher Sprigman, The Piracy Paradox: Innovation and Intellectual Property in Fashion Design, 92 VA. L. Rev. 1687, 1698-99 (2006) (coining the term "low-IP equilibrium").

5. See id. at 1764 (coining and defining the term "negative space"). 
erty's negative spaces. ${ }^{6}$ Most have conducted case studies, examining such diverse areas as fashion, ${ }^{7}$ cuisine,${ }^{8}$ magic tricks, ${ }^{9}$ stand-up comedy, ${ }^{10}$ typefaces,${ }^{11}$ free and open-source software, ${ }^{12}$ sports, ${ }^{13}$ wikis, ${ }^{14}$

6. For a general discussion of negative spaces, see KAL Raustiala \& Christopher Sprigman, The KnOCKOFF ECONOMY (2012).

7. See generally Raustiala \& Sprigman, supra note 4 (focusing on the lack of intellectual property protection for fashion designs); Kal Raustiala \& Christopher Sprigman, The Piracy Paradox Revisited, 61 StAN. L. Rev. 1201 (2009) (clarifying and expanding on the arguments explored in Piracy Paradox and responding to scholarly proposals for legislative reform).

8. See generally Christopher J. Buccafusco, On the Legal Consequences of Sauces: Should Thomas Keller's Recipes Be Per Se Copyrightable?, 24 Cardozo Arts \& Ent. L.J. 1121 (2007) (exploring the copyrightability of recipes and concluding that economic, public policy, and cultural considerations counsel against extending copyright protection to recipes); Emmanuelle Fauchart \& Eric von Hippel, Norms-Based Intellectual Property Systems: The Case of French Chefs, 19 ORG. SCI. 187, 187-88 (2008) (arguing that recipes are better protected by self-enforced social norms than by intellectual property law); Jessica Litman, The Exclusive Right to Read, 13 CARdozo Arts \& ENT. L.J. 29, 44-45 (1994) (reexamining the bargain between copyright holders and the public that copyright entails and arguing that nascent industry can be stimulated by lack of copyright protection); Raustiala \& Sprigman, Piracy Paradox, supra note 4, at 1768; J. Austin Broussard, Note, An Intellectual Property Food Fight: Why Copyright Law Should Embrace Culinary Innovation, 10 VAnd. J. EnT. \& TECH. L. 691 (2008) (arguing for copyright protection for chefs' innovative recipes as original works of authorship).

9. See generally Jacob Loshin, Secrets Revealed: Protecting Magicians' Intellectual Property Without Law, in Law And Magic: A Collection of Essays 123 (Christine A. Corcos ed., 2010) (describing the ways in which the magic community has developed social norms that protect intellectual property in the absence of IP law).

10. See generally Dotan Oliar \& Christopher Sprigman, There's No Free Laugh (Anymore): The Emergence of Intellectual Property Norms and the Transformation of Stand-Up Comedy, 94 VA. L. REv. 1787 (2008) (arguing that intellectual property law is not a cost-effective way to protect creativity of stand-up comedians and that social norms provide a substitute for IP law).

11. See Blake Fry, Why Typefaces Proliferate Without Copyright Protection, 8 J. Telecomm. \& High TeCH. L. 425, 432-37 (2010) (arguing for the continued exclusion of typefaces from copyright protection and explaining why that exclusion does not prevent innovation). See generally Jacqueline D. Lipton, To (C) or Not to (C)? Copyright and Innovation in the Digital Typeface Industry, 43 U.C. Davis L. Rev. 143 (2009) (calling for Congress, the Copyright Office, and courts to reexamine the issue of typeface copyrightability and arguing for, at most, thin protection for digital typefaces).

12. See generally, e.g., Yochai Benkler, Coase's Penguin, or, Linux and The Nature of the Firm, 112 YALE L.J. 369 (2002) (analyzing the economic and cultural implications of peer production of information).

13. See, e.g., F. Scott Kieff et al., It's Your Turn, but It's My Move: Intellectual Property Protection for Sports “Moves," 25 Santa Clara Computer \& High Tech. L.J. 765, 766, 774-76 (2009) (arguing that the use of IP rights in sports gives more bargaining power to a much broader range of athletes); Gerard N. Magliocca, Patenting the Curve Ball: Business Methods and Industry Norms, 2009 BYU L. REv. 875, 877 (2009) (arguing that "there should be a presumption against considering a process patentable subject matter under 35 U.S.C. $§ 101$ when a norm can be found in the relevant industry against patenting the class of innovations at issue").

14. See generally Jon M. Garon, Wiki Authorship, Social Media, and the Curatorial Audience, 1 Harv. J. Sports \& Ent. L. 95 (2010) (arguing for a wiki model in which collaboration is encouraged but normative expectations of authorship are maintained). 
academic science, ${ }^{15}$ jambands, ${ }^{16}$ hip-hop music, ${ }^{17}$ tattoo artists, ${ }^{18}$ and even roller derby pseudonyms. ${ }^{19}$ Negative spaces like these are crucial pieces of the intellectual property law puzzle. They prove that people create even when they are not guaranteed exclusive control over their creations. For that reason, negative spaces tend to undermine the conventional wisdom that intellectual property law is necessary to promote creation and innovation. But while scholars have paid increasing attention to these areas, none have articulated the importance of shame and shaming in creating and maintaining them.

I submit that shame and shaming are not only major factors in generating negative spaces, but also may help guide our understanding of intellectual property law more generally. Shame and shaming regulate behavior in many settings, but they cannot substitute for formal law. They are too variable, and in some cases are harmful. But shame and shaming are valuable nonetheless: first, they modulate the law, making it stronger or weaker depending on community needs; second, they highlight where the law may draw lines in the wrong places. The role of shame and shaming in creating and governing negative spaces implies that people gravitate toward "set points" of intellectual property protection. They create intellectual property rules where none exist, and they rail against the rules when they are too restrictive. Examining shame and shaming in the intellectual property context indicates what people value in various creative settings and teaches that

15. See Keith Aoki, Authors, Inventors and Trademark Owners: Private Intellectual Property and the Public Domain (pt. 2) 18 Colum.-VLA J.L. \& Arts 191, 207 (1994) (explaining that academic scientists are driven by "desires to obtain priority and to gain professional recognition, promotions, grants, tenure and increased funding" to publish their research regardless of intellectual property incentives). See generally Katherine J. Strandburg, Curiosity-Driven Research and University Technology Transfer, in University ENTREPRENEURShiP AND TeChNOlogy Transfer: Process, Design, and Intellectual Property 93 (Gary D. Libecap ed., 2005).

16. See Mark F. Schultz, Fear and Norms and Rock \& Roll: What Jambands Can Teach Us About Persuading People to Obey Copyright Law, 21 Berkeley Tech. L.J. 651, 653, 676-77 (2006) (describing the ways in which the jamband community uses social norms to enforce copyright law).

17. See generally Horace E. Anderson, Jr., "Criminal Minded?”: Mixtape DJs, the Piracy Paradox, and Lessons for the Recording Industry, 76 Tenn. L. Rev. 111 (2008) (extending Raustiala and Sprigman's "piracy paradox" from the fashion industry to mixtapes and arguing for a model that employs strategic forbearance of copyright enforcement); Horace E. Anderson, Jr., No Bitin' Allowed: A Hip-Hop Copying Paradigm for All of Us, 20 Tex. Intell. Prop. L.J. 115 (2011) (describing copying norms in hip-hop music).

18. See generally Aaron Perzanowski, Tattoos \& IP Norms, 98 Minn. L. REv. (forthcoming 2013); Matthew Beasley, Note, Who Owns Your Skin: Intellectual Property Law and Norms Among Tattoo Artists, 85 S. Cal. L. Rev. 1137 (2012).

19. See generally David Fagundes, Talk Derby to Me: Intellectual Property Norms Governing Roller Derby Pseudonyms, 90 TEx. L. Rev. 1093 (2012) (investigating the extralegal governance scheme used to protect derby names to explain the emergence of subcultural IP norms). 
the level and details of communities' set points may vary from community to community.

As we consider the proper boundaries of intellectual property protection, therefore, we should consider the roles of shame and shaming in shaping creation, innovation, and copying. This Article first explores the operation of shame and shaming. ${ }^{20}$ Next, it examines the relationships between shame, shaming, and formal law, first generally and then in the intellectual property context. ${ }^{21}$ This is followed by an analysis of the benefits and drawbacks of shame and shaming as regulatory mechanisms. ${ }^{22}$ The Article concludes with a brief discussion of the normative implications of shame and shaming for intellectual property law. ${ }^{23}$ While shame and shaming do not-and should notreplace formal law, they influence it and sometimes stand in its shoes. When considering whether to implement new protections and whether to carve out exceptions to current protections, lawmakers should take into account how shame and shaming will interact with formal rules, and they should consider whether formal enactments will add value beyond shame-based enforcement.

\section{Shame And Shaming}

While shame and shaming share common roots, they operate somewhat differently. Shame is a painful emotion of self-judgment, generated by the person who experiences it. ${ }^{24}$ Shaming is an external, and generally public, appeal to the shame of another. ${ }^{25}$ Thus, while both rely on the concept of shame, the entity that feels shame or gets shamed may experience them quite differently. Nevertheless, both have the potential to be powerful shapers of behavior.

\section{A. Shame Defined}

Shame is the natural response of psychologically healthy individuals when they fail to conform to their own values or to the prevailing values of their family or social community. For example, people might experience shame if they lie, which is contrary to the value "lying is wrong." Both an excess of shame and the lack of it are associated

\footnotetext{
20. See infra Part II.

21. See infra Part III.A.

22. See infra Part III.B.

23. See infra Part IV.

24. See generally Andrew P. Morrison, Shame: The Underside of Narcissism 5 (1989) (taking a psychoanalytic approach); Raúl López-Pérez, Guilt and Shame: An Axiomatic Analysis, 69 Theory \& Decision 569 (2010) (economic); Heidi L. Maibom, The Descent of Shame, 80 Phil. \& Phenomenological Res. 566 (2010) (philosophical).

25. John Braithwaite, Crime, Shame and Reintegration 100 (1989).
} 
with psychological pathology-neuroticism and psychoticism, respectively. ${ }^{26}$ But in limited amounts, shame is not only normal and healthy, but also a necessary element of social cohesion. ${ }^{27}$ Shame prevents chaos by motivating people to follow the norms of society and civilization: they conform, at least in part, because they would be ashamed not to.

Shame operates in the gap between ambition and achievement. Psychologically, people are strongly motivated to align their "actual self" with their "ideal self" and their "ought self." 28 People feel shame when there is a negative gap between their aspiration level ("I aspire to be a generous person ...") and their perceived self on that trait (". . . but I am selfish sometimes"). ${ }^{29}$

What is "shameful" varies widely from culture to culture, but the phenomenon of shame is universal and has even been identified in nonhuman animals. ${ }^{30}$ Recent studies have shown that shame may have genetic roots, evolving naturally through individual selection. ${ }^{31}$ This makes sense. In addition to enhancing social cohesion, shame benefits those who experience it, as they are less likely to run afoul of rules, and by extension, less likely to experience punishment. Indeed, statistical modeling shows that people who experience shame should have longer life spans than those who do not. ${ }^{32}$

While shame is innate, what people are ashamed of is defined largely through their interactions with others. Social science research has demonstrated that people consciously or subconsciously absorb and internalize the social norms of community influences such as family, religion, profession, neighborhood, and politics. ${ }^{33}$ Each commu-

26. See Thomas J. Darvill et al., Personality Correlates of Public and Private Self Consciousness, 13 Personality \& Individual Differences 383 (1992) (experimentally correlating excessive shame with neuroticism and a lack of shame with psychoticism).

27. See Klaus Jaffe, Simulations Show that Shame Drives Social Cohesion, in Advances in Artificial Intelligence - IBERAMIA-SBIA 2006 88, 90 (Jaime Simao Sichman et al. eds., 2006) (using simulations to model the function of shame in society).

28. See Volkan Topalli, When Being Good is Bad: An Expansion of Neutralization Theory, 43 CRIminology 797, 799 (2005) (discussing shame and norms in active hard-core criminal communities).

29. See López-Pérez, supra note 24 , at 579.

30. See Maibom, supra note 24, at 577-78.

31. Herbert Gintis, The Hitchhiker's Guide to Altruism: Gene-Culture Coevolution, and the Internalization of Norms, 220 J. Theoretical Biology 407, 414-15 (2003) (positing and modeling genetic development of altruism as a shame-enforced internal norm); Klaus Jaffe, Evolution of Shame as an Adaptation to Pro-Social Punishment and Its Contribution to Social Cohesiveness, Complexity, Nov.-Dec. 2008, at 46 (basing findings on computer simulations of genetic development through natural selection).

32. See Jaffe, supra note 27 , at 93.

33. See Norbert Elias, The Civilizing Process 492 (Edmund Jephcott trans., Blackwell Publishers 1994) (1939); see also López-Pérez, supra note 24, at 575 (describing internalization). 
nity has a set of beliefs that are generally accepted among community members and are partly sustained by their approval. ${ }^{34}$ Some social norms are widely held, such as manners and etiquette, honesty norms, and the norm against cannibalism. But many social norms vary from community to community. ${ }^{35}$ When people are, or aspire to be, members of a particular community, they see themselves as embodying the ideals of that community. Acting or desiring something inconsistent with those ideals will automatically generate shame. ${ }^{36}$ Shame therefore acts as an enforcer of community norms and values.

Shame does not require an audience per se, ${ }^{37}$ but it does depend on some conception, either real or imagined, of what others would think. Experiencing shame demands either being observed by others-peers, respected authorities, customers, social cohort, society at large-or seeing oneself as one presumes others would. ${ }^{38}$ When people are "ashamed of themselves," therefore, it is because they have internalized a value they ascribe to others and see in themselves a failure to embody that value. In the words of Jean-Paul Sartre: "Shame is by nature recognition. I recognize that I am as the Other sees me." 39

Shame is related to, but different from, guilt. Although many use the terms interchangeably in common parlance, they differ to social scientists: guilt is based on individual transgressions, while shame is based on a perceived failure or defect of the whole self. ${ }^{40}$ For instance, the sentiment that "I did something wrong," differs from the feeling that "there's something wrong with me." Guilt and shame depend on each other to shape behavior through the "guilt-shame cy-

34. See López-Pérez, supra note 24, at 572 (defining social norms).

35. See id. at 575; see also Topalli, supra note 28 , at 801 (providing an example of a community, street criminals, with idiosyncratic norms).

36. Elias, supra note 33, at 492; see also Morrison, supra note 24, at 32 (discussing relationship between shame and the "ego ideal"); $i d$. at 79 (discussing relationship between shame and the threat of rejection or abandonment by a "significant object"); López-Pérez, supra note 24, at 575-79 (describing shame's operation in shaping behavior through aversion to norm-breaking).

37. Experimental evidence tends to show that behavior need not be observed to generate shame. For example, failure feedback has proven to generate shame even when given privately by computer without a human experimenter present. David E. Conroy \& Aaron L. Pincus, Interpersonal Impact Messages Associated with Different Forms of Achievement Motivation, $79 \mathrm{~J}$. Personality 675, 694 (2011) (citing Holly A. McGregor \& Andrew J. Elliot, The Shame of Failure: Examining the Link Between Fear of Failure and Shame, 31 Personality \& Soc. Psychol. Bull. 218 (2005)).

38. Maibom, supra note 24 , at 569.

39. Jean-Paul Sartre, Being and Nothingness 222 (Hazel E. Barnes trans., Gramercy Books 1994) (1956).

40. See Morrison, supra note 24, at 5; see also Maibom, supra note 24, at 568; June P. Tangney et al., Shame, Guilt, and Remorse: Implications for Offender Populations, 22 J. Forensic Psychiatry \& Psychol. 706, 707 (2011) (criminological); John Wilson, Shame, Guilt and Moral Education, 30 J. Moral Educ. 71, 72 (2001) (moral and literary). 
cle."41 People feel guilty when they transgress, and then they feel shame for being the sort of person who would do something worthy of guilt. ${ }^{42}$ ("There is something wrong with me because I want/embody/ am willing to do something inconsistent with society's expectations/ norms/mores.") For this Article's purposes, however, the difference between guilt and shame is less important than the difference between shame and shaming.

\section{B. Shaming Defined}

While shame is a reflexive, internal emotion, shaming is an external, aggressive action-an appeal to the shame of another, generally before a public audience. Shaming may have many motivations, including a desire to impose norms on another, to trigger someone else's shame, or to inflict reputation-based punishment. Regardless of the motivation, shaming appeals to community norms and attempts to impose them on someone else.

Sociologically, shaming includes "all social processes of expressing disapproval which have the intention or effect of invoking remorse in the person being shamed or condemnation by others who become aware of the shaming." 43 Shaming may take many forms: scolding, rebuking, ridiculing, scorning, avoiding, and shunning are all varieties of shaming sanction. ${ }^{44}$ Shaming is often, but not always, directed at stigmatizing a transgressor. As Dan Kahan has explained, public shaming may take the form of stigmatizing publicity (e.g., publishing a list of "johns" to stigmatize those who violate anti-prostitution norms); literal stigmatization (e.g., compelling someone to wear a badge identifying herself as a transgressor); self-debasement (e.g., requiring someone to perform a publically debasing act, such as carrying a sign stating that she stole from a particular retailer); or contrition (e.g., requiring a public apology). ${ }^{45}$ Although shaming may be directed privately at the transgressor, it is usually also directed at a broader audience.

Thus, most shaming has two audiences. First, it is directed at the "shamed" entity, as it may cause the target to internalize the values of the shamers or to experience feelings of shame. Second, it is directed

\footnotetext{
41. Morrison, supra note 24, at 11.

42. See id.

43. Braithwaite, supra note 25 , at 100 .

44. Edna Ullmann-Margalit, The Case of the Camera in the Kitchen: Surveillance, Privacy, Sanctions, and Governance, 2 Reg. \& Governance 425, 435 (2008).

45. See Douglas Litowitz, The Trouble with 'Scarlet Letter' Punishments, 81 Judicature 52, 54-55 (1997) (citing Kahan, Alternative Sanctions, supra note 3, at 631) (describing Kahan's taxonomy).
} 
to a community of listeners who share the shamers' values and who may judge the target according to those values. For example, shaming is a core element of picketing: striking workers' signs say, "Shame on [employer]," not only to hurt the employer's feelings, so to speak, but also to harm the employer's reputation-and by extension, its bottom line.

\section{How Shame and Shaming Shape Behavior}

Both shame and shaming are powerful behavior shapers. ${ }^{46}$ Sometimes they work in concert: members of a community adhere to norms and ideals both because they want to avoid feeling shame and because they want to avoid being shamed or expelled from the community. ${ }^{47}$ Although the two forces may complement each other, they operate differently: shame operates through automatic self-restraint, whereas shaming operates through conscious manipulation by others. ${ }^{48}$ As a result of this difference, the behavioral effects of shaming are more complex, and less reliable, than the behavioral effects of shame.

\section{Shame}

People fear shame because shame is painful. Long ago, Emile Durkheim, Talcott Parsons, and other social researchers posited that people often comply with internalized norms in order to avoid experiencing shame, and this conclusion has been reinforced by more recent experimental evidence regarding brain activity. ${ }^{49}$ In fact, research indicates that shame is more powerful than law in shaping behavior. For example, empirical studies have shown that shame is more effective than rules at securing compliance with college anti-underage drinking policies; ${ }^{50}$ that appeals to conscience are more successful than threats

46. See generally, e.g., Liang-Chih Chang, The Effects of Moral Emotions and Justifications on Visitors' Intention to Pick Flowers in a Forest Recreation Area in Taiwan, 18 J. Sustainable TOURISm 137 (2010) (correlating moral emotions of guilt, embarrassment, and shame with their propensity to violate flower-picking rules in a park); Topalli, supra note 28, at 801 (reporting that hard-core criminals are less likely to engage in snitching and other behaviors of which they would be ashamed).

47. See Charles R. Tittle et al., A Test of a Micro-Level Application of Shaming Theory, 50 Soc. Probs. 592, 594 (2003).

48. See Steven Russell, Reintegrative Shaming and the 'Frozen Antithesis': Braithwaite and Elias, 34 J. Soc. 303, 306-08 (1998) (comparing Braithwaite's concept of shaming to Elias' concept of shame).

49. López-Pérez, supra note 24, at 570.

50. See Margaret S. Kelley et al., Deterrence Theory and the Role of Shame in Projected Offending of College Students Against a Ban on Alcohol, 39 J. Drug Educ. 419, 432 (2009). 
of punitive sanction in securing compliance with tax laws; ${ }^{51}$ and that hard-core criminals will avoid informing on others, even when informing would have legally beneficial effects, because they are ashamed to "snitch." 52 Thus, shame may drive someone to refrain from behavior even when formal law permits it, or to engage in behavior even when formal law prohibits it. ${ }^{53}$

Shame derives its power from community identity. Commercial chefs, for example, internalize the values "it's bad to copy someone's recipe exactly" and "it's important to give credit to chefs who develop significant recipes." ${ }_{54}$ Accordingly, chefs comply with the norms of originality and attribution associated with those values. Members of the open-source movement internalize the ideal "software sharing is good" and comply with the distribution and license-proliferation norms associated with it. ${ }^{55}$ When people violate community norms, they feel a threat to their very identities. ${ }^{56}$ This makes the fear of shame so potent that people follow community norms even when the norms may not be in their immediate interest. For example, someone who has internalized the value of sharing software code will do so even in cases where sharing the software code might be financially harmful, or where keeping it secret might be financially beneficial. ${ }^{57}$

Shame effectively shapes even unobserved and unobservable behavior, because violators of community norms fear losing identity or self-respect. ${ }^{58}$ Thus, shame can enforce norms even when they are

51. See Linda Brennan \& Wayne Binney, Fear, Guilt, and Shame Appeals in Social Marketing, 63 J. Bus. Res. 140, 142 (2010) (citing James W. Harvey \& Kevin F. McCrohan, Is There a Better Way of Improving Compliance with the Tax Laws? Insights from the Philanthropic Literature, 7 J. Pub. Pol'y \& Marketing 138, 140 (1988)).

52. See Topalli, supra note 28 , at 801 (reporting that hard-core criminals are less likely to engage in snitching and other behaviors of which they would be ashamed).

53. See Fagundes, supra note 19, at 1147-48 (discussing the thin line between law and norms as sources of coercive behavior shaping).

54. See Fauchart \& von Hippel, supra note 8, at 188; see also Buccafusco, supra note 8, at 1154.

55. See Lawrence Lessig, Open Code and Open Societies: Values of Internet Governance, 74 Chi.-Kent L. Rev. 1405, 1417 (1999) ("This is the core of the Open Source Movement: that the code of open source software remains free for others to take, and modify, and use: that it sits in the public domain, which means that no one needs the permission of anyone else to take it, and improve it.").

56. See Wilson, supra note 40 , at 79.

57. See Gintis, supra note 31, at 408; see also López-Pérez, supra note 24, at 570 (positing that shame drives compliance with norms that are inconsistent with selfishness).

58. See Posner \& Rasmusen, supra note 3 , at 371 . This is the prevailing, modern view. Some theorists still maintain that shame requires an audience to function. See, e.g., Eugene Kandel \& Edward P. Lazear, Peer Pressure and Partnerships, 100 J. Polit. Econ. 801, 806 (1992) (arguing that shame is generated by external pressure and thus shapes behavior only when behavior is observable). 
sporadically or non-uniformly enforced, as long as community members understand those norms to be community values or ideals.

\section{Shaming}

Shaming, unlike shame, does not rely exclusively on internalization, but also operates through public perception. Shaming can make a broader audience-members of a community who share the values of the shamer-dislike the shamed entity, and therefore can harm even an entity that does not share the community's values. Shaming sanctions, such as shunning, can harm an entity's reputation, identity, or even profitability. Other shaming sanctions, such as rebuke and recrimination, can lead to humiliation-the "manifestation of shame which is the product of action perpetrated against the self by someone else." 59 This in turn results in an actual or presumed loss of reputation. Since entities want to avoid the disapproval of others, they tend to avoid behavior that would lead to public shaming. Thus, public shaming may shape behavior even when the shamed entity has not internalized the value in question-but it is doubtless most effective when the shamed entity also experiences internal shame as a result of having internalized the value. ${ }^{60}$ In those settings, shaming has the potential to be more powerful than physical or pecuniary punishment. Growing up, many children are far more moved by hearing a parent say, "I am ashamed of you," than by other punishments, such as being spanked or having their allowance reduced. The same reasoning extends to the context of formal legal punishment.

Shaming can also work on firms-collective entities such as corporations, partnerships, and associations. Because shame is a human emotion, firms cannot "have shame" as natural people do. Firms lack the emotional mechanisms required to feel, process, or react to shame. But this is not to say that shame has no influence on firm behavior. Firms are comprised of people who (unless they are pathological) undoubtedly experience shame. Individuals' shame may particularly influence small or closely held corporations, and may influence larger firms as well, because the shame of a firm's leaders will at least partially guide the firm's behavior. But the collective shame-driven behaviors of multiple individuals-who may not have internalized the same, or even consistent, values-is less predictable than the individual shame-driven behavior of a single person. In addition, the exis-

59. See Morrison, supra note 24, at 15.

60. See Nathan Harris, Reintegrative Shaming, Shame, and Criminal Justice, 62 J. Soc. Issues 327 (2006) (discussing relationship between reintegrative shaming, stigmatization, and experience of shame-guilt). 
tence of a corporate structure, and the presence of other people as a buffer, may make larger corporate entities systematically insusceptible to shame, as they may permit individuals to avoid taking internal responsibility for any value-betraying desires. Therefore, although individuals within a firm will experience their own shame, the firm as a whole cannot be expected to "have shame" as the individuals do.

Although shame may not control corporate entities, public shaming can. It is often effective: we can all think of countless instances in which corporations, universities, sports teams, and the like have been effectively shamed into changing their policies. ${ }^{61}$ Research shows that shaming works on corporations largely because they are concerned with reputation. ${ }^{62}$ As social scientist Raúl López-Pérez queries, "[W]hy should firms spend huge amounts of money in efforts to improve society and safeguard the environment, guided by ideas of Corporate Social Responsibility . . . , if [they thought] nobody cared about that?"63 In the intellectual property context, Internet shaming has unquestionably influenced the behavior of potential IP bullies. Many attorneys now advise against sending cease-and-desist letters to "gripe site" operators ${ }^{64}$ —even letters the senders might believe to be "reasonable"-because of the risk that a site operator will post the letter publicly, harming the sender's reputation. ${ }^{65}$

The reasoning behind this response may be cynical rather than ethical: firms make business decisions based on what will help or harm

61. For just a few examples, see Microsoft's reversal of its Xbox One policies, Andrew Goldfarb, Microsoft: 'Shame on Us' for Xbox One Messaging: Xbox One Chief Product Officer Marc Whitten Responds to Fans' Concerns, IGN (July 12, 2013), http://www.ign.com/articles/2013/07/ 12/microsoft-shame-on-us-for-xbox-one-messaging; Nike's transformation of its manufacturing conditions and transparency, Max Nisen, How Nike Solved Its Sweatshop Problem, Business INSIDER (May 9, 2013, 10:00 PM), http://www.businessinsider.com/how-nike-solved-its-sweatshop-problem-2013-5; and Rutgers' firing of abusive basketball coach Mike Rice, Mike Lupica, Mike Rice Finally Fired for his Actions but Shame on Rutgers if All Involved in the Player Abuse Scandal Don't Also Get the Ax, N.Y. Daily News (Apr. 3, 2013, 9:30 AM), http://www. nydailynews.com/sports/college/lupica-shame-rutgers-don-fire-involved-article-1.1306415.

62. See James Q. Whitman, What Is Wrong with Inflicting Shame Sanctions?, YALE L.J. 1055, 1066-67 (1998).

63. See López-Pérez, supra note 24, at 570 (footnote omitted) (establishing via economic modeling that shaming drives such corporate norms).

64. Gripe sites are websites dedicated to the public shaming of people or corporations. For a general collection of gripe sites, see WeBGripeSites.COM, http://www.webgripesites.com/ (last visited Sept. 18, 2013). There are countless examples of gripe sites posting cease-and-desist letters they have received. See, e.g., JP Morgan Chase is Officially Pissed Off About This Site, ChASE BANK Sucks (Jan. 3, 2009), http://www.chase-sucks.com/11/jp-morgan-chase-is-officiallypissed-off-about-this-site/.

65. See Rachael Braswell, Consumer Gripe Sites, Intellectual Property Law, and the Use of Cease-and-Desist Letters to Chill Protected Speech on the Internet, 17 Fordham Intell. Prop. Media \& Ent. L.J. 1241, 1287-88 (2007). 
their bottom lines. But even these decisions depend on firms' presumptions about the shame-based values of consumers, as consumers generally want to patronize businesses they approve of. Consumers feel shame when they support businesses that betray their values. ("I am ashamed to be the sort of person who supports a business that pollutes the environment or engages in other practices I abhor.") Businesses want prospective consumers to see them as embodying the consumers' values and are therefore keenly aware of the reputational impact of shaming. While public shaming may not trigger the "shame" of a business per se, it may compel a business to feign shame for reputational and, by extension, commercial purposes.

One might assume that public shaming is a more powerful behavior shaper than internal shame because public shaming works in two ways-emotionally and reputationally-while internal shame works only emotionally. But the contrary is true: as a behavior shaper, shaming is actually less predictably effective than shame. The effects of shame on individual emotion are automatic, but the effects of shaming are not. Shaming, unlike shame, depends on the beholder.

Shaming demands, at least in part, that the target have basic respect for the shamer's opinion, or the opinions of the shamer's audience. Shaming has little effect if the target perceives its actions to be justified or misunderstood: "If the violator shrugs off the criticisms as a product of ignorance, malice, or envy, and in addition anticipates no bad effects on him from the reception of the criticisms by other people, the criticisms will fail as sanctions for the criticized act."66 This has particularly broad implications for firms, as they cannot experience the emotional aspect of shaming. Shaming, therefore, has little power over firms that do not depend on public opinion for profits or market share. ${ }^{67}$ A firm that believes its reputation does not "matter" may simply ignore any attempts at shaming. 68 Indeed, even if reputation-based shaming does influence public opinion, firms may brush it off if they don't perceive the "public" as significant enough to affect profits. An oil company can tolerate being labeled a "polluter," and a

66. Posner \& Rasmusen, supra note 3, at 374; see also Litowitz, supra note 45, at 55; John Rothchild, Protecting the Digital Consumer: The Limits of Cyberspace Utopianism, 74 IND. L.J. 893, 968 (1999) (noting that shaming is ineffective in policing, for example, "the behavior of junk e-mailers, who do not shrink from antagonizing the vast majority of the recipients of their marketing").

67. See Amy Morganstern, Comment, In the Spotlight: Social Network Advertising and the Right of Publicity, 12 Intell. Prop. L. Bull. 181, 196-97 (2008) (noting mixed effectiveness of collective shaming action in motivating corporate entities, particularly those with market-dominant products such as Google and Facebook).

68. See Posner \& Rasmusen, supra note 3 , at 380. 
manufacturer an "exploiter of workers," unless they believe that a meaningful number of relevant purchasers care enough to buy exclusively from "eco-friendly" and "worker-friendly" companies. 69 In addition, different people may hold different, and sometimes diametrically opposed, values regarding what is shameful. While some viewed the public announcement by restaurant chain Chick-FilA that it supported anti-gay causes as shameful, others thought it worthy of celebration. ${ }^{70}$ In the absence of an authoritative consensus regarding what constitutes good-type or bad-type behavior, shame and shaming cannot provide consistent governance and will inevitably be unsatisfying for some portion of the population.

Furthermore, reputation-based shaming is unlikely to matter unless it reaches the ears and eyes of people who care. For example, although the website Chilling Effects Clearinghouse (Chilling Effects) performs the valuable service of collecting overzealous cease-and-desist letters and takedown notices, ${ }^{71}$ there is no way of knowing whether Chilling Effects succeeds in reducing the aggressiveness of IP bullies. For every Internet shaming campaign that reaches its audience, there may be dozens of attempts at shaming that few people ever become aware of. And while Internet shaming may be growing as a method of enforcing community values on perceived transgressors, ${ }^{72}$ the capacity of listeners may not be growing commensurately. Some percentage of shaming campaigns, therefore, will just be shouting into the wind - and it is difficult, if not impossible, to predict which ones.

In addition, shaming works best if the transgressive behavior is either rare or rarely detected. Studies have shown that once behavior is common, it becomes accepted, and shaming is no longer effective as a

69. In its early stages, therefore, public shaming may be more of an attempt to create public "buy-in" for a particular value than an attempt to shape firm behavior. Once a particular market community internalizes a value, firms seeking that community's business will be forced to conform to that value - to market themselves as "eco-friendly" or "worker-friendly" - but may not see any reason to do so earlier. Similarly, early-stage shaming may be an attempt to invite (or coerce) a firm into a particular community by trying to convince the firm that the community is large or influential enough to merit conforming to the community's values.

70. See Joe Satran, Chick-Fil-A Sales Soar in 2012 Despite Bad PR, Huffington Post (Jan. 31, 2013, 12:24 PM), http://www.huffingtonpost.com/2013/01/31/chick-fil-a-sales-2012_n_2590612. html.

71. See Chilling Effects Clearinghouse, http://www.chillingeffects.org (last visited Sept. 18, 2013).

72. See generally Leah Chan Grinvald, Shaming Trademark Bullies, 2011 WIs. L. REv. 625; Ira S. Nathenson, Civil Procedures for a World of Shared and User-Generated Content, 48 U. LouisVILLE L. REv. 911, 951 (2010) ("[P]ublic-interest groups and other advocates play a major role in criticizing overreaching copyright enforcement at the systemic level."). 
punishment or deterrent. ${ }^{73}$ Similarly, shaming may actually promote bad behavior when the behavior is common, since it may highlight the fact that "everyone is doing it." 74 In the intellectual property context, this carries an ironic twist: the more that IP bullies are shamed, the less their practices may be seen as shameworthy.

Empirical studies show that, even in individuals, shame is a more powerful behavior shaper than shaming. One study established that, although both shame and shaming were more effective than rules in securing students' compliance with college underage drinking policies, students' internal shame was more influential than external shaming penalties, such as "name and shame" lists or embarrassment.75 Another study found that appealing to taxpayers' consciences was more successful in securing their compliance with tax laws than threatening them with punitive sanctions. In addition, the study found that voluntary compliance is more likely when an action is deemed important in the wider society or community. Thus, people are motivated more by community approval than by community scorn. ${ }^{76}$

These findings reflect that while the pain of shame is automatic, the pain of shaming can be circumvented by rejecting the shamer's values. Shaming can even generate rage and rebellion. ${ }^{77}$ The stigmatizing effect of shaming can drive targets out of a community instead of pulling them in, creating "outsiders" who feel they owe nothing to the community and feel no discomfort in transgressing. ${ }^{78}$

\section{Disintegration vs. Reintegration}

Social scientists have struggled to discern what causes shaming to backfire into rage or rebellion. The most prominent theory originates with sociologist John Braithwaite, whose work focuses predominantly on shaming and crime. Braithwaite divides shaming practices into "disintegrative" and "reintigrative" varieties. ${ }^{79}$ Disintegrative shaming stigmatizes offenders by alienating them from a community. Thus,

73. See Posner, supra note 3, at 1789-90 (discussing the creation and enforcement of norms in the tax context and more generally).

74. See Litowitz, supra note 45, at 56.

75. Kelley et al., supra note 50, at 432-33.

76. Brennan \& Binney, supra note 51, at 142 (citing James W. Harvey \& Kevin F. McCrohan, Is There a Better Way of Improving Compliance with the Tax Laws? Insights from the Philanthropic Literature, 7 J. Pub. Pol'y \& Marketing 131, 140 (1988)).

77. See Rodogno, supra note 3, at 434 (discussing relationship between humiliation and negative effects in connection with shaming penalties).

78. See Anne-Marie McAlinden, The Use of 'Shame' with Sexual Offenders, 45 Brit. J. CRIMINOLOGY 373, 379 (2005) (discussing the disintegrative effects of naming and shaming sex offenders).

79. See Braithwaite, supra note 25 , at 55. 
disintegrative shaming may not prevent unwanted behavior-and in fact, may promote it-because instead of creating an incentive to conform to norms, stigmatization creates outcasts who reject community values and consequently repeat their behavior without fear of emotional pain.

In contrast, reintegrative shaming incorporates some notion of forgiveness or repentance and a renewed relationship with the offender. Braithwaite argues that it is therefore much more effective at preventing crime (and by extension, other behaviors unacceptable to the prevailing community). In his words, "the key to crime control is cultural commitments to shaming in ways that I call reintegrative." 80 Unlike stigmatization,

[r]eintegrative shaming ... is disapproval dispensed within an ongoing relationship with the offender based on respect, shaming which focuses on the evil of the deed rather than on the offender as an irremediably evil person, where degradation ceremonies are followed by ceremonies to decertify deviance, where forgiveness, apology, and repentance are culturally important. ${ }^{81}$

Where disintegrative shaming tells the transgressor, "you are bad," reintegrative shaming tells the transgressor, "do better next time."

Braithwaite's theory is instinctively appealing, but incomplete. Other studies show that the effectiveness of shaming depends on interdependency between the shamer and the transgressor. ${ }^{82}$ These findings are consistent with the limits of shaming discussed above: reputation-based shaming works only if (1) it is actually likely to influence the target's reputation and (2) the target cares. In short, an offender who feels no relationship with the shamer is not the fittest candidate for reintegration.

\section{Shame, Shaming, and Law}

Shame, shaming, and law share a long common history as systems of social control. At a fundamental level, shame and formal law are intertwined. In most cases, formal law embodies the values of society, and breaking the law is considered per se shameful. ${ }^{83}$ This shame

80. Id. at 1 .

81. John Braithwaite, Shame and Modernity, 33 BRIT. J. CRIMINology 1, 1 (1993).

82. See Carter Hay, An Exploratory Test of Braithwaite's Reintegrative Shaming Theory, $38 \mathrm{~J}$. Res. Crime \& Delinq. 132, 147-48 (2001) (empirical test demonstrating that "the negative effect of shaming was not dependent on the level of reintegration").

83. See Tom R. Tyler, Why People Obey the Law 62-63 (1990); see also Catherine A. Sanderson \& John M. Darley, "I Am Moral, but You Are Deterred": Differential Attributions About Why People Obey the Law, 32 J. Applied Soc. Psychol. 375, 375-78 (2002); Cass R. 
functions even when people may not agree with a particular law: even someone who believes that drugs should be legalized may refrain from taking drugs because it is illegal—and thus shameful- to take them. ${ }^{84}$

Shaming, too, has long been used as a tool of law enforcement. Historians have tracked the existence of parallel and complimentary systems of law and shaming at least as far back as ancient Greece, and anthropologists have found it to be a universal phenomenon. ${ }^{85}$ Shaming penalties-ranging from public physical punishments such as whippings and hangings to more psychologically driven shaming via stocks or pillories-were common forms of formal law enforcement imposed by religious and state authorities in colonial America. ${ }^{86}$ Shaming's popularity as an official penal technique waned in the nineteenth century, likely due in part to the influence of the Quakerswho advocated for rehabilitative and educative punishment-and partly to social science work of the day, which favored swift, certain punishment over more flamboyant options. ${ }^{87}$

Today, so-called scarlet letter punishments have returned to vogue as alternatives to the cost and time of prison. A Milwaukee judge offered reduced jail time to a convicted drunk driver who agreed to wear a sandwich board publicly admitting his crime. ${ }^{88}$ One Florida judge commonly sentences thieves to carry a sign in front of the place they stole from, stating, "I stole from this store," in lieu of fines or jail time. ${ }^{89}$ Public shaming via apology and advertisement are also on the

Sunstein, On the Expressive Function of Law, 144 U. PA. L. REv. 2021, 2025-28 (1996); Jensen, supra note 2, at 562 ("However, legal rules can also induce compliance with the law indirectly by changing the social meaning of unlawful conduct. As Cass Sunstein has observed, defining certain conduct as 'against the law' can 'inculcate both shame and pride' in the minds of individuals ....").

84. See Robert J. MacCoun, Drugs and the Law: A Psychological Analysis of Drug Prohibition, 113 Psychol. Bull. 497, 501 (1993) ("[T]he mere fact that an act is illicit might have an influence on behavior that is independent of the actual magnitude of the threat of punishment.").

85. See Sara Forsdyke, Street Theatre and Popular Justice in Ancient Greece: Shaming, Stoning and Starving Offenders Inside and Outside the Courts, 201 PAST \& PRESENT 3, 4-6 (2008); see also Toni M. Massaro, Shame, Culture, and American Criminal Law, 89 Mich. L. Rev. 1880, 1904-15 (1991).

86. See Litowitz, supra note 45 , at 53-54.

87. See id. at 54.

88. See id. at 52.

89. This American Life, 379: Return To The Scene of the Crime (Public Radio International radio broadcast May 1, 2009), available at http://www.thisamericanlife.org/radio-archives/episode/379/return-to-the-scene-of-the-crime (the description of the episode reads: "There's a town in Florida where if you shoplift, and get caught, a judge will send you back to the scene of your crime to stand in front of the store, with a large sign that reads 'I stole from this store.' Ira [Glass] and producer Lisa Pollak talk to one such teenager who was caught stealing from a convenience store, the supervisor overseeing her punishment, and the judge who sends her there."). 
rise as formal punishments for white-collar crime. Informal extrajudicial shaming, such as conducting a "perp walk" for white-collar criminals, is similarly growing in popularity..$^{90}$ Furthermore, several states publish lists of tax offenders. ${ }^{91}$ In most contexts, shame and shaming reinforce formal law. There are a few outlying exceptions to this: for example, in communities of hard-core criminals, shame reinforces anti-"snitching" norms that conflict with law enforcement. ${ }^{92}$

\section{A. IP, Specifically}

The outlying exception in the criminal context seems to be the norm in the intellectual property context: While shame and shaming reinforce formal intellectual property law in some ways, they may actually do even more to work against it. Shame and shaming create rules where formal intellectual property law provides none; and where formal law does provide rules, shame and shaming limit enforcement.

For many, intellectual property infringement is shameful, just as violating criminal law is. By labeling certain conduct as "infringing," society identifies it as transgressive, and potential offenders refrain from infringing because they fear the shame of transgressing. External shaming reinforces this; it is likely that shaming has been an informal remedy for unauthorized copying for as long as there has been unauthorized copying. ${ }^{93}$ Recently, the Recording Industry Association of America (RIAA) employed several varieties of shaming to stem the tide of infringing music piracy. First, the RIAA's highly publicized suits against file sharers made examples of a few file sharers-a modern-day pillory-and reinforced the concept that infringement is shameful. ${ }^{94}$ Second, the RIAA's advertising campaign explicitly labeled peer-to-peer file sharing "theft," which likened file sharing to an established shameful behavior and may have triggered the shame mechanism in many who had not previously viewed file sharing as

90. See John M. Ivancevich et al., Formally Shaming White-Collar Criminals, 51 Bus. HorIzONS 401, 403-405 (2008).

91. Id. at 404.

92. See Topalli, supra note 28 , at 801 (reporting that hard-core criminals are less likely to engage in snitching and other behaviors of which they would be ashamed).

93. See, e.g., H. Tomás Gómez-Arostegui, The Untold Story of the First Copyright Suit Under the Statute of Anne in 1710, 25 Berkeley Tech. L.J. 1247, 1302-06 (2010) (describing how parties to the first copyright suit in 1710 had previously used public shaming via printed handbills as a remedy for copying when formal protection was not available).

94. See Julie E. Cohen, Pervasively Distributed Copyright Enforcement, 95 Geo. L.J. 1, 9 (2006). 
shameful. ${ }^{95}$ This example demonstrates how external shaming can define what is shameful. Although a great deal of music file sharing takes place today, some reports say that it has declined somewhat, ${ }^{96}$ and many people doubtless elect to not engage in file sharing because they have internalized anti-file sharing values. People, whether they share files or not, are now more likely to believe that file sharing is "wrong." 97

File sharing is only one example of this phenomenon. Because small-scale copyright and patent infringements are difficult to detect, most potential infringers would probably never be caught. But they are guided by conscience; they refrain from infringing not because they fear enforcement, but because they believe infringement is shameful. In that way, shame and shaming operate in the intellectual property law context exactly as they do in other contexts. ${ }^{98}$ But shame and shaming also do something else in the IP context: they supplant and re-form formal law, creating restrictions and freedoms that formal law does not. Shame and shaming are major factors in creating intellectual property's negative spaces - areas of creation and innovation that thrive without significant formal intellectual property protection. These areas are important because they tend to defy the conventional wisdom that intellectual property exclusivity is universally necessary as an incentive for creation and innovation. Understanding what makes these areas function, therefore, helps us understand when formal protection is, and is not, needed.

95. See id. at 18 ("Entertainment industry representatives have deployed a variety of rhetorical tropes designed to position online copyright infringement, and particularly $\mathrm{p} 2 \mathrm{p}$ filesharing, as morally objectionable and socially insidious.").

96. See, e.g., Press Release, NPD Grp., The NPD Group: Music File Sharing Declined Significantly in 2012 (Feb. 26, 2012), available at https:/www.npd.com/wps/portal/npd/us/news/pressreleases/the-npd-group-music-file-sharing-declined-significantly-in-2012/ (reporting a $17 \%$ decline in the number of consumers using peer-to-peer file sharing services between 2011 and 2012).

97. According to a 2003 Gallup poll, $15 \%$ of teens aged 13-17 believed it was "morally wrong" to download music from the Internet for free. Steve Hanway \& Linda Lyons, Teens OK with Letting Music Downloads Play, Gallup.com (Sept. 30, 2003), http://www.gallup.com/poll/ 9373/teens-letting-music-downloads-play.aspx. Six years later (when the individuals who took the Gallup survey were all over age 18), a CBS poll found that $30 \%$ of young adults aged 18-29 believed that online music sharing was "never acceptable." Bootie Cosgrove-Mather, Poll: Young Say File Sharing OK, CBSNews (Feb. 11, 2009, 8:29 PM), http://www.cbsnews.com/2100500160_162-573990.html. See also Herkko Hietanen et al., Criminal Friends of Entertainment: Analysing Results from Recent Peer-to-Peer Surveys, 5 SCRIPTED 31, 39 (2008) ("Nearly half of the users [of illegal file sharing sites] saw the use of illegal file sharing sites as morally questionable. Evidently the file sharers are not breaking the law because they are unaware of it." (footnote omitted)).

98. See, e.g., Tyler, supra note 83; Kahan, Alternative Sanctions, supra note 3, at 603. 
Shame and shaming create and govern these spaces in two ways. First, in some creative communities, shame and shaming govern copying behavior when there is no formal law in place. Second, shame and shaming help discourage intellectual property owners from enforcing their intellectual property rights in overreaching ways. Shame and shaming are therefore among the factors that help to sustain low-IP equilibria.

\section{Fear: Shame and "IP Without IP"}

When people have internalized values regarding copying, they are ashamed to violate them, regardless of what the law dictates. This is just as true in areas where formal intellectual property law does not reach-areas that I call "doctrinal no man's land" 99 — as it is in areas well controlled by formal intellectual property law. The result is that, in doctrinal no man's land, individuals conform to community norms regarding copying without the strictures of formal law, creating "IP without IP."100

Even when formal law might permit copying in various contexts, shame prevents it, or shapes the behavior of would-be copiers. For example, copyright fair use rules allow scholars to rely on quotations from other scholars' work, ${ }^{101}$ and law does not require attribution to the original work. Yet scholars still cite each other when they use quotations. Scholars even cite each other when there is no meaningful risk that their plagiarism would be discovered, as when relying on obscure sources or student research. Why cite? Taking credit for another's ideas might, especially in a world without anti-plagiarism norms, be beneficial to the plagiarist. But we live in a world that values citation, and scholars have internalized that norm. Scholars would be ashamed to take credit for others' work (and rightly so). Perhaps scholars share other concerns as well: a desire for reciprocal citation, for example, or a desire to appear well-read. But a great many, no doubt, cite because they believe it would be wrong not to.

Empirical case studies indicate that scholars are not alone in adhering to copying and attribution norms because they would be ashamed not to. Haute cuisine chefs maintain an unspoken, yet well-defined,

99. See Elizabeth L. Rosenblatt, A Theory of IP's Negative Space, 34 Colum. J.L. \& ArTs 317,325 (2011) (defining "doctrinal no man's land” as one type of negative space).

100. See Rochelle Cooper Dreyfuss, Does IP Need IP? Accommodating Intellectual Production Outside the Intellectual Property Paradigm, 31 CARdozo L. Rev. 1437, 1439 (2010) (defining IP without IP as "Intellectual Production without Intellectual Property").

101. See 17 U.S.C. $§ 107$ (2006) (including "scholarship, or research" among the categories of fair uses of copyrighted material). 
set of sharing, anti-copying, and attribution norms that differ significantly from the strictures of formal law. ${ }^{102}$ Roller derby participants register their pseudonyms in a sport-wide database and consult that database before choosing pseudonyms. Although the law is silent on the question of roller derby pseudonym copying, the participants know that copying would betray community values, and being part of the community is "central to the derby experience." 103 Tattoo artists will copy trademarks and copyrighted works onto clients' skin, but refrain from copying custom tattoos; they enforce these norms through notions of self-respect, shame, and shaming rather than formal legal remedies. ${ }^{104}$ Comedians refrain from copying not only expression (as copyright law would demand), but also ideas, because they believe joke-stealing is wrong. ${ }^{105}$ Typeface designers avoid copying designs verbatim because to do so would be "dirty pool."106 Free-software advocates "see avoiding proprietary or commercial entanglements as a moral imperative." 107

Although the interviewees in these case studies seldom use the word "shame," they consistently refer to notions of conscience and community values in identifying the taboos and obligations of their particular negative spaces. This amounts to shame: the fear that if they do not conform, they would be failing to live up to the values of their community. This is distinct from concerns about shaming, humiliation, or the embarrassment of being exposed, although certainly each of those may play a part in the decision to comply with community norms. ${ }^{108}$ Rather, it is about internalizing values, desiring to live up to them, and fearing the emotional pain of shame that would result from betraying those values.

Thus, the individual, internal shame of participants helps to sustain the delicate equilibrium of low-IP negative spaces, where creation

102. See Buccafusco, supra note 8 at 1151-55; see also Fauchart \& von Hippel, supra note 8, at 191-94.

103. Fagundes, supra note 19 , at 1126-28.

104. See Beasley, supra note 18 , at $1162-68$ (reporting tattoo artists' prevailing view that "copycats are not true artists" and describing ways in which shame and shaming govern tattoo artists' conduct).

105. As one experienced stand-up comedian explained to me, "It's not just fear of being exposed as a joke-stealer and what other people think. It's partly that, but it's also about why you're doing stand-up in the first place. Stand-up is all about being original. If you're not being original, you're nothing.” Interview with John Rogers, in L.A., Cal. (February 10, 2013).

106. Lipton, supra note 11, at 169 (quoting Leslie CABARgA, Logo, Font, ANd Lettering Bible 12 (2004)).

107. Timothy K. Armstrong, Shrinking the Commons: Termination of Copyright Licenses and Transfers for the Benefit of the Public, 47 HaRv. J. ON LEGIs. 359, 369 n.47 (2010).

108. Interview with John Rogers, supra note 105. 
thrives without significant formal intellectual property protection. In these communities, the law permits copying-even unlimited or unrestricted copying. One might expect that freedom to copy would undermine the incentive to create in those areas. It does not, likely because creators in those areas are motivated by reasons other than exclusivity or direct pecuniary benefit. For example, creators may create out of a desire for recognition or a desire to be part of a creative community. For creators who desire recognition, a community that permits widespread copying but demands attribution is ideal. ${ }^{109}$ Creators who merely desire community membership do best to find a creative community and adhere to its norms, whatever they may be. In either case, the creator will be highly motivated to conform to community norms, and will feel shame for violating them, because those very norms are among the creator's reasons for joining the community. And even if a creator does not possess the community's values at the outset, the creator will eventually internalize them and feel shame for violating them.

Like the norm against snitching in criminal circles, here shame arises from doing something that is perfectly legal. The shameful behavior may even be salutary from a broader societal perspective, but it violates community norms. Perhaps society would benefit from more imitations of haute cuisine recipes. But because the behavior is taboo among a relevant segment of society-other chefs and "foodies"chefs generally refrain from copying. ${ }^{110}$ Shame may be an ideal enforcement mechanism when formal law will not work. For example, performance magicians have great difficulty relying on formal law to protect their tricks, because seeking or enforcing protection would usually require disclosing one's secrets. Instead, magicians abide by a culture of secrecy, policed by shame. ${ }^{111}$ Where formal law leaves off, shame takes over.

Because they are backed by the power of shame, these norms-based systems are more sustainable than they might appear. One might expect a handful of self-interested rogues to stray from a norms-based system, thereby causing it to collapse. According to Rochelle Cooper Dreyfuss, a number of factors may contribute to the breakdown of negative spaces, which highlights the fragility of low-IP equilibria. ${ }^{112}$

109. See Rosenblatt, supra note 99, at 343-45.

110. See Fauchart \& von Hippel, supra note 8, at 187-88 (discussing community reactions to recipe copying); $c f$. Topalli, supra note 28 , at 810 (discussing participants' guilt and shame for violating the norm against snitching in active hard-core criminal communities).

111. See Jacob Loshin, supra note 9, at 134-35.

112. See Rochelle Dreyfuss, Fragile Equilibria, VA. L. Rev. In BRIEF (Jan. 22, 2007), http:// www.virginialawreview.org/inbrief.php?s=inbrief $\&$ p=2007/01/22/dreyfuss (describing "bounded 
Yet the norms persist. While shame-based norms depend on a stable conception of what constitutes good-type behavior, ${ }^{113}$ they will not change easily. Change requires a transformation in attitudes rather than a handful of selfish defectors.

Many negative-space communities of individuals, as distinct from those inhabited mostly by firms, exhibit signs of the "interdependence" that makes shame and shaming most effective. ${ }^{114}$ Although a tattoo artist could work in a vacuum, most rely on each other for business and professional growth. ${ }^{115}$ Open-source creators depend on each other for crowdsourcing and technical support. ${ }^{116}$ Stand-up comedians depend on each other for bookings and moral support in what could otherwise be a crushingly lonely existence. ${ }^{117}$

These are communities in which public shaming would be effective, and occasionally it occurs: dozens of YouTube videos expose alleged joke-stealers. ${ }^{118}$ Tattoo "plagiarist hall of shame" galleries show examples of norm violators. ${ }^{119}$ Academic science plagiarists may be "named and shamed" in journals. ${ }^{120}$ Foodies draw attention to menus that seem "plagiarized." 121 But for the most part, low-IP subcultures seem not to depend on shaming. Even people who believe they can "get away with it" will adhere to community values because, as a matter of conscience, they want to see themselves as someone who be-

altruism, tipping, herding, failed leadership, and technological change" as likely factors contributing to the breakdown of negative spaces).

113. See Posner, supra note 3, at 1789-90 (discussing signaling-type norms).

114. See Braithwaite, supra note 25 , at $85-87$ (recognizing that shaming is more effective in "communitarian" societies, defined as societies whose members are interdependent).

115. Perzanowski, supra note 18 (manuscript at 36) ("[G]ossip can have serious social and professional consequences.").

116. See Gregg P. Macey, Cooperative Institutions in Cultural Commons, 95 Connell L. Rev. 757, 776-77 (2010).

117. Interview with John Rogers, supra note 105.

118. See, e.g., Joe Rogan, Joe Rogan VS Carlos Mencia, ONSTAGE VIDEO, YouTube (Jan. 23, 2013), http://www.youtube.com/watch?v=gdugSUFbzws; see also Oliar \& Sprigman, supra note 10, at 1821, 1825 (describing Internet popularity of clip showing feud between Joe Rogan and Carlos Mencia and a "recent spate of comic shaming videos on YouTube").

119. See, e.g., Guen Douglas, How to Avoid Tattoo Plagiarism, TAM Blog (Mar. 15, 2012), http://tattooartistmagazineblog.com/2012/03/15/guen-douglas-how-to-avoid-tattoo-plagiarism/; Shannon Larratt, Tattoo Plagiarism, MODBLog (Sept. 21, 2005), http://news.bme.com/2005/09/ 21/tattoo-plagiarism/; NickBAXTER.сOM, http://www.nickbaxter.com/facemaster.cfm?Thread_ PageNum_search $=6 \&$ PageNum_search $=2 \&$ task=message_list\&thread_index $=105061 \&$ generate $=1 \&$ topic_index $=10$ (last visited Sept. 9, 2013, 5:06 PM); NYArtman, Plagiarist Hall of Shame, NYArtman.com (Apr.27, 2011, 10:01 PM), http://www.nyartman.com/index.php?option=com content \&view=article \&id=292: plagiarist-hall-of-shame \&catid=3:blog-rants\&Itemid=65.

120. See 'Index 2007: Names of Plagiarists': Is Naming and Shaming the Answer?, Bioethics, Nov. 2007, at ii.

121. See Buccafusco, supra note 8, at 1122 (describing one such event on the culinary blog eGullet.org). 
longs. This is consistent with case studies about negative spaces: some are close-knit, like the communities of roller derby participants or elite tattoo artists, ${ }^{122}$ but others are not. Most lack barriers to entry. ${ }^{123}$ Yet even in the open-source community, where it would be nearly impossible to know who is toeing the line and who is not, certain core values prevail: distributed software creation is good; sharing is good; closed licensing is bad. ${ }^{124}$ These values spread, even though the open-source community is geographically far-flung; the Internet permits effective dissemination of common values, and shame follows. ${ }^{125}$

These communities rely on a network of custom and internal enforcement to develop norms and teach new members what behaviors are accepted and what behaviors are shameful. This shame-teaching takes place largely informally, through simple communications within the community. It may also involve requesting that community members conform, ${ }^{126}$ shaming within the community, or denying members future community benefits. Chefs, for example, are less likely to share recipes with those who betray community values. ${ }^{127}$ Tattoo artists will personally confront or badmouth those who copy custom tattoos. ${ }^{128}$ Performance magicians will stop associating with colleagues who reveal how tricks are performed; when a rogue magic trick manufacturer sold unauthorized illusions, a long list of respected magicians signed a letter shaming the manufacturer. ${ }^{129}$ These informal enforcement mechanisms teach community members what constitutes good-type and bad-type behavior, so that they will be driven by conscience to comply with norms regardless of whether they are likely to be caught. In this way, negative-space communities conduct shame-teaching through a combination of custom-communicating norms and values

122. Fagundes, supra note 19, at 1101; Beasley, supra note 18, at 1167.

123. See, e.g., Schultz, supra note 16, at 679 (noting that in the jamband community, "membership is fluid, often anonymous, and requires no membership card").

124. See Lessig, supra note 55, at 1417 ("This is the core of the Open Source Movement: that the code of open source software remains free for others to take, and modify, and use: that it sits in the public domain, which means that no one needs the permission of anyone else to take it, and improve it.").

125. See Braithwaite, supra note 81, at 13-15 (1993) (discussing urban varieties of community in the context of reintegrative shaming).

126. For example, the University of Virginia's Electronic Text Center, which houses many public domain texts, is concerned principally with archival dependability when it begs users not to copy its texts for commercial use or mount them on other servers. Brad Bedingfield, Note, Copyrighting Medieval Literature: Editing and Publishing the Pre-Modern Public Domain, 28 Colum. J.L. \& Arts 213, 244-45 (2005).

127. Fauchart \& von Hippel, supra note 8, at 193.

128. Beasley, supra note 18 , at 1167.

129. Loshin, supra note 9, at 138. 
to each other-and enforcement techniques, such as shaming, denial of reciprocal benefits, and even expulsion for those who fail to comply.

Thus, each negative-space creative community makes its own copying and attribution norms, and the participants in the community are compelled by shame, and to some extent, shaming, to comply with them. Because they arise organically from within the community, these norms are customized to the needs of the greater community. ${ }^{130}$ They may not serve each participant ideally, but they are more likely to suit participants' needs than the one-size-fits-all approach of formal law, which is not only imposed from the outside to suit the needs of external constituencies like major entertainment companies, but is also designed to work across all industries and creative endeavors. ${ }^{131}$

\section{Loathing: Shaming and IP Forbearance}

While internal shame prevents copying, external shaming encourages it. More accurately, external shaming discourages intellectual property owners from aggressively enforcing their rights. When copyright, patent, or trademark owners send cease-and-desist letters, the Internet makes it easy to shame the intellectual property owners by accusing them of bullying or being trolls. In so doing, shamers create a public conversation that transforms intellectual property owners into "bad guys" simply for enforcing their own rights. This discourse uses the language of shaming to shape the reaction of the shamed entity and to build public opinion. The terms "troll" and "bully" signal shameful identity just as the terms "junkie" and "slut" signal shamingbased condemnation of drug use and female sexuality. ${ }^{132}$

The Internet creates a panopticon. ${ }^{133}$ The instant an intellectual property owner sends a cease-and-desist letter, that letter can be

130. See Fagundes, supra note 19, at 1136-37 (discussing the flexibility of the derby name regulation system).

131. See Dan L. Burk \& Mark A. Lemley, Policy Levers in Patent Law, 89 VA. L. Rev. 1575 , 1577 (2003) (arguing that a formal, unitary patent system is ill-equipped to manage the diverse range of industries it must cover).

132. See Polly Radcliffe \& Alex Stevens, Are Drug Treatment Services Only for 'Thieving Junkie Scumbags'? Drug Users and the Management of Stigmatised Identities, 67 Soc. ScI. \& MED. 1065, 1066 (2008) (discussing the shaming and stigmatizing effect of the "junkie" label); Lori Rackl \& Andrew Herrmann, Women Trekking Back to Their Dorm in the Morning After a Hookup Take the 'Walk of Shame.' For Guys, It's the 'Stride of Pride.' College Women Today. .., Chi Sun-Times, Mar. 21, 2005 (discussing gender-based double-standard and shame-based condemnation of female "sluts").

133. See Jeremy Bentham, Proposal for a New and Less Expensive Mode of Employing and Reforming Convicts, 6 Brittanic Magazine 403, 406 (1798) (“[A] building circular . . . the prisoners in their cells . . . . By blinds and other contrivances, the Inspectors concealed . . from the observation of the prisoners: hence the sentiment of a sort of invisible omnipresence. The 
posted to the Internet for the whole world to see. And when a shamer begins the discourse, the shamer controls it; when a shamer introduces an IP owner to the world as a bully or troll, the world sees that intellectual property owner through the shamer's eyes. This gives accused infringers the power to turn the accusation around and impose sharing norms on IP-holding entities that may be big and powerful.

Indeed, fear of external shaming may act prophylactically, preventing powerful intellectual property owners from overextending their rights. ${ }^{134}$ One commentator advises that "[i]n a classic 'David versus Goliath' battle, throngs of people come to the defense of the small business owner" who is perceived to be at the mercy of the larger corporate giant. ${ }^{135}$ Attorneys are increasingly aware that "enforcement can bring unwanted negative publicity."136 Sending a cease-anddesist letter carries with it an enormous risk of negative attention. The phenomenon is so well-known that it has a name: the Streisand Effect. ${ }^{137}$ The name originated in 2003, when photographer Ken Adelman and his wife sought to document California coastal erosion by photographing the entire California coast from a helicopter and posting their results on the website www.californiacoastline.org. These photos included and identified an aerial view of Barbara Streisand's estate. ${ }^{138}$ Streisand demanded the photo be removed, first via cease-and-desist letter ${ }^{139}$ and later via lawsuit, which the Los Angeles Superior Court dismissed. ${ }^{140}$ The ironic result was that Streisand not only failed to get the photos removed, but also drew massive attention to the photo. Reports state that the image was downloaded just six times prior to the suit but was accessed as many as 420,000

whole circuit reviewable with little, or . . . without any, change of place. One station in the inspection part affording the most perfect view of every cell . . ..").

134. See Ullmann-Margalit, supra note 44, at 432-33 (discussing the chilling effect of surveillance on behavior).

135. John Sternal, How to Trademark Shame a Larger Company, Small Bus. Trends (Mar. 8, 2012), http://smallbiztrends.com/2012/03/how-to-trademark-shame-a-larger-company.html.

136. William T. Gallagher, Trademark and Copyright Enforcement in the Shadow of IP Law, 28 Santa Clara Computer \& High Tech. L.J. 453, 494 (2012).

137. See What Is the Streisand Effect?, EcONOMIST (Apr. 15, 11:50 PM), http://www.economist. com/blogs/economist-explains/2013/04/economist-explains-what-streisand-effect.

138. See Paul Rogers, Photo of Streisand Home Becomes an Internet Hit, San Jose Mercury NEws, June 24, 2003, at 1B, available at http://www.californiacoastline.org/news/sjmerc5.html.

139. Letter from John M. Gatti, Attorney, Alschuler Grossman Stein \& Kahan LLC, to Kenneth Adelman (Feb. 10, 2003), available at http://www.californiacoastline.org/streisand/threat. pdf.

140. Complaint at 21, Streisand v. Adelman, No. SC 077257 (Cal. Super. Ct. Dec. 31, 2003), available at $\mathrm{http}: / /$ www.californiacoastline.org/streisand/complaint.pdf; Statement of Decision at 45, Streisand v. Adelman, No. SC 077257 (Cal. Super. Ct. Dec. 31, 2003), available at http:// www.californiacoastline.org/streisand/slapp-ruling.pdf. 
times in the month after Streisand's suit was filed. ${ }^{141}$ By taking legal action, Streisand created exactly the opposite of her desired result. Her experience and scores of others have taught intellectual property owners that it is risky to assert one's rights, especially when the rights are weak or the alleged infringer has many sympathizers.

Shaming influences not only whether, but also how, intellectual property owners enforce their rights. Savvy IP owners know that their cease-and-desist letters may be posted on the Internet, so they incorporate more reasonable demands and make them less threatening in tone. ${ }^{142}$ When asserting trademark rights, they shift responsibility away from themselves, relying on the so-called duty to police to appear more practical and less overbearing. ${ }^{143}$ By seeming reasonable, intellectual property owners can not only avoid being shamed, but can develop positive reputations. They can harness the shame of consumers who would be ashamed to patronize companies who betray the consumers' values. Jack Daniel's garnered positive attention, for example, by sending an exceedingly friendly cease-and-desist letter to an author who parodied the Jack Daniel's label on a book cover, with a jovial tone and a more limited set of demands than an average letter of its kind. ${ }^{144}$ Regardless of the motivation, these moves gradually shift intellectual property owners' behavior toward the shamers' values and away from maximal enforcement.

In the Internet age, shaming campaigns have the potential to spread virally. Social media sites like Facebook help harness network effects to spread shaming messages; the more "likes" a shaming campaign garners, the larger an audience it reaches. ${ }^{145}$ In addition, sites like Chilling Effects seek to harness this phenomenon by collecting and indexing aggressive cease-and-desist letters. Chilling Effects thereby identifies IP bullies and labels them as such. ${ }^{146}$ Similarly, for years,

141. Ruling on Submitted Matters, Tentative Decision and Proposed Statement of Decision at 6, Streisand v. Adelman, No. SC 0772577 (Cal. Super. Ct. Dec. 3, 2003), available at http://www. californiacoastline.org/streisand/slapp-ruling-tentative.pdf; Rogers, supra note 138.

142. See Gallagher, supra note 136, at 495 (quoting an interviewed attorney's statement: "You always know that a letter you send can be on the Internet that same day, so you write it accordingly.").

143. See David E. Armendariz, Note, Picking on the Little Guy? Asserting Trademark Rights Against Fans, Emulators, and Enthusiasts, 90 Tex. L. Rev. 1259, 1267-68 (2012) (discussing instances in which trademark holders have claimed that pursuit of enthusiasts was rooted in duty to police rather than desire to pursue).

144. See Debra Cassens Weiss, Jack Daniel's Cease-and-Desist Letter Goes Viral for Being Exceedingly Polite, A.B.A. J. (July 26, 2012, 9:38 AM CDT), http://www.abajournal.com/news/ article/jack_daniels_cease-and-desist_letter_goes_viral_for_being_exceeedingly_poli/.

145. See Grinvald, supra note 72, at 627 (describing a Facebook shaming campaign conducted by a small brewery against a large, multi-million dollar company).

146. See Chilling Effects Clearinghouse, supra note 71. 
the Patent TrollTracker blog named and shamed patent assertion entities. $^{147}$

These attempts not only shift public opinion about the shamed entities, but also create public opinion about what constitutes good-type and bad-type behavior. Until Patent TrollTracker embarked on its campaign of naming and shaming patent assertion entities, few had ever heard of a "patent troll," and few had an opinion at all about the moral propriety of being in the patent litigation business. But by creating a discourse of shame around patent assertion behavior, Patent TrollTracker (and many others who took part in the conversation) made the patent assertion business model shameful-or at least ethically questionable. ${ }^{148}$ Large-scale campaigns have even influenced the path of formal law. In 2011 and 2012, shaming campaigns drew attention to proposed Internet IP regulations known as the Stop Online Piracy Act (SOPA) and the PROTECT-IP Act (PIPA), mixing market and electoral power with the language of shame and ultimately defeating the laws' passage. ${ }^{149}$

Shaming sends the message that certain values are important enough for the target to adopt (or at least perform) them. If environmentalists did not shame polluters, the polluters might not perceive a sufficient reason to justify the expense of avoiding it. Merely drawing attention to polluting behavior would not produce the same result because attention alone, without normative content, does not create or reinforce values. Shaming not only draws attention to the behavior, but also reinforces to all who listen-including the target and the public at large - that the behavior in question is wrong.

By shaming a target, shamers invite the target to become a part of the shamers' community value system. Shamers not only threaten the

147. The original Patent TrollTracker blog has since been discontinued. However, earlier posts from the blog have been archived and are available at Patent TrollTracker Resurrected, TECH Rights, http://techrights.org/patent-trolltracker/ (last visited Sept. 23, 2013).

148. See, e.g., Lisa A. Dolak \& Blaine T. Bettinger, The United States Patent System in the Media Mirror, 58 Syracuse L. Rev. 459, 487-89 (2008) (identifying "patent trolls" as among the most common media criticisms of the U.S. patent system).

149. See Cory Doctorow, SOPA/PIPA Mashup: How Much Hollywood Money Did Your Lawmaker Take? Name and Shame with Fellow Voters, BoINGBoing (Jan. 21, 2012, 6:24 AM), http://boingboing.net/2012/01/21/sopapipa-mashup-how-much-hol.html (shaming legislators who supported the bills); see also Mark Gibbs, No Blackout for SOPA/PIPA? We Know Who You Are, Computerworld (Jan. 20, 2012, 10:27 AM), http://www.computerworld.com/s/article/ 9223589/No_blackout_for_SOPA_PIPA_We_know_who_you_are.?pageNumber=1 (shaming websites that did not participate in public demonstration against bills); Alex Wilhelm, For Shame! Microsoft's Continued Support of the PROTECT IP Act is Disgraceful, The Next Web, (Dec. 26, 2011, 5:19 AM), http:/thenextweb.com/microsoft/2011/12/26/for-shame-microsoftscontinued-support-of-the-protect-ip-act-is-disgraceful/ (shaming Microsoft, a corporate supporter of the bills). 
target, but also reintegrate it (in the Braithwaitean sense) by giving the target an opportunity to be forgiven-to "do better next time." If the target adopts or performs the shamers' values, it has the opportunity to join the shamers' community. In addition, if the shamers and the target are at all interdependent, a reformed target will gain customers, or at least stop losing them. Thus, reintegrative shaming is possible even outside the context of insular communities.

Were it not for shaming, IP bullies might not appreciate the number and potency of those who care about pro-sharing values or attribution. A few recent incidents highlight this. In June 2012, the United States Olympic Committee (USOC) sent a cease-and-desist letter to the fiber-arts community Ravelry, demanding that the community stop using the term "Ravelympics" for a community event. ${ }^{150}$ The USOC was well within its rights to send the letter: in fact, the Olympic and Amateur Sports Act (OASA), which grants it exclusive rights in the term "Olympics," is significantly stronger than the trademark rights granted by the Lanham Act, as the OASA does not provide infringers with the same expression-based exceptions. ${ }^{151}$ Ravelry changed the name of its event to the Ravellenic Games, ${ }^{152}$ even though there was little likelihood that Ravelry's use of the suffix "-lympics" would cause confusion or harm to the USOC's mark. But the fiber-arts community members were not as ready to accept what it saw as bullying, and they reacted virulently. Over two days, the community generated over 2,300 furious message board posts, and the story went viral to news outlets like Gawker, Slate, and NPR. ${ }^{153}$ As a result, the USOC learned a lesson, or at least appeared to: it posted a formal letter of

150. See Adrian Chen, Knitters Outraged After U.S. Olympic Committee Squashes Knitting Olympics—and Disses Knitters, GAwKer (June 20, 2012, 5:44 PM), http://gawker.com/5920036/ us-olympics-committee-is-mad-at-knitting-olympics-for-denigrating-real-athletes?tag=olympics (reproducing letter).

151. See 36 U.S.C. § 220506 (2006).

152. See Mary Mooney, USOC Wins the Olympic Battle, but Ravelry Wins the War, ThE OreGONIAN (June 27, 2012, 2:37 PM), http://blog.oregonlive.com/knitting/2012/06/usoc_wins_the_ olympic_battle_b.html.

153. See For the Love of Ravelry (forum), RAVELRY, http://www.ravelry.com/discuss/for-thelove-of-ravelry/2189293/1-25 (Ravelry account required) (including a moderator post observing users' anger: "If you cannot contribute in respectful manner then you need to find another place to post. ... [I]f you guys can't reel it in, we'll have to. We will lock this thread permanently if it comes to that."); see also Chen, supra note 150; Will Oremus, Mob of Angry Knitters Takes the Gold in Battle with U.S. Olympic Committee, SLATE (June 22, 2012, 3:52 PM), http://www.slate. com/blogs/future_tense/2012/06/22/ravelry_olympics_usoc_apologizes_to_online_knitting_community_over_trademark_crackdown.html; Mark Memmott, After Knitters Get In A Twist, USOC Apologizes for 'Cease And Desist' Letter, NPR (June 21, 2012, 1:55 PM), http://www.npr.org/ blogs/thetwo-way/2012/06/21/155508908/after-knitters-get-in-a-twist-usoc-apologizes-for-ceaseand-desist-letter. 
apology to the community stating, among other things, that it "embrace[s] hand-crafted American goods."154

In January 2013, the Fox television show Glee broadcast a cover version of the Sir Mix-A-Lot song "Baby Got Back" that was copied, note-for-note, from a version by independent artist Jonathan Coulton. This was par for the course: Glee had copied covers before, including covers from artists DJ Earworm, Greg Lasswell, and Nouvelle Vague. ${ }^{155}$ This did not constitute infringement because, as a function of the compulsory licensing scheme for creating cover songs, cover artists do not own rights in their cover versions. If a cover version of a song is close enough to the original that it fits within the compulsory licensing scheme, the cover does not constitute infringement of the original. But by making something so similar to the original, the cover artist essentially gives up the right to argue that he or she added anything original to the song. ${ }^{156}$ As a practical matter, a listener might find a cover version to be quite novel, but the law says differently. Thus, Fox and Glee have the right to copy cover songs without permission from the cover maker, as long as they enter into the appropriate licenses with the original song creator. With Coulton, however, this approach backfired: Coulton is a standard-bearer for the Creative Commons community and its pro-sharing, pro-attribution values. When Coulton made a blog post about Glee's unauthorized use of his cover, the Internet exploded with outrage at Glee's choice not to attribute the cover to Coulton. ${ }^{157}$ Although Glee was not required by law to give credit to Coulton, the community shamed Glee and Fox, in essence inviting them to join the community's pro-attribution values. It is still too soon to say whether the campaign has had any effect on Fox's attribution practices, but it has generated enough attention to touch Fox's bottom line: in a few days on iTunes, sales of Coulton's

154. Statement from USOC Spokesperson Patrick Sandusky, TeAm USA (June 21, 2012, 12:07 PM), http://www.teamusa.org/News/2012/June/21/statement-from-usoc-spokesperson-patricksandusky.aspx.

155. See Laura Hudson, Jonathan Coulton Explains How Glee Ripped Off His Cover Songand Why He's Not Alone, Wired (Jan. 25, 2013, 3:21 PM), http://www.wired.com/underwire/ 2013/01/jonathan-coulton-glee-song/; see also Nicola Roberts, A Collection of Covers Glee Borrowed from Other People, Livejournal (Jan. 25, 2013, 6:23 AM), http://ontd-glee.livejournal. com/2513279.html.

156. 17 U.S.C. $§ 115(a)(2)$ (“A compulsory license includes the privilege of making a musical arrangement of the work to the extent necessary to conform it to the style or manner of interpretation of the performance involved, but the arrangement shall not change the basic melody or fundamental character of the work, and shall not be subject to protection as a derivative work under this title, except with the express consent of the copyright owner.").

157. See Michele Catalano, Jonathan Coulton vs. Glee and Fox Update: Last Laughs, Forbes (Jan. 31, 2013, 8:17 PM), http://www.forbes.com/sites/michelecatalano/2013/01/31/jonathancoulton-vs-glee-and-fox-update-last-laughs/. 
"Baby Got Back - In the Style of Glee" (with all proceeds going to charity) sold more units than any track actually produced by Glee. ${ }^{158}$

Although these stories demonstrate the communicative power of shaming, they also demonstrate its unpredictability. While each has felt the effects of shaming, there is no guarantee that either the USOC or the producers of Glee will change their enforcement or attribution behaviors in the long term. The shamers invited both entities to join their norms-communities, but it remains to be seen whether either will join. We can be sure, however, that each shamed target has a newfound awareness that competing norms exist—something they may not have known before the shaming occurred. Likewise, consumers can rely on the shaming to make decisions about whether they want to support the Olympics or watch Glee. This demonstrates the discursive aspect of shaming: it carries information about what the shamers believe is, and should be, shameful.

\section{B. Strengths and Weaknesses of Shame and Shaming as Regulatory Mechanisms}

As regulatory mechanisms, shame and shaming have a number of significant benefits, even as compared with formal law: they are more democratizing, more flexible, and sometimes more effective at governing behavior. But it would be a mistake to assume that these benefits make shame and shaming optimal tools for regulating copying in all circumstances. In fact, both shame and shaming have significant flaws and risks. Shame only affects a small portion of the population, and shaming, although it applies more universally, is far less likely to be effective. Both shame and shaming have the potential to be deeply damaging. For that reason, they are not adequate replacements for formal law. I suggest that in an ideal intellectual property system, they would augment, not supplant law, serving more as tools for understanding proper levels of protection rather than as regulatory mechanisms in and of themselves.

\section{A Few Strengths}

Many of the strengths of shame and shaming as regulatory mechanisms are discussed above: shame, and to some extent shaming, compels people to comply with laws and norms, even when their transgressions would likely never be discovered. ${ }^{159}$ In the intellectual property context, shame and shaming allow communities to customize

158. $I d$.

159. See supra Part II.C.1. 
copying and attribution norms to the needs and wants of particular creative communities. ${ }^{160}$ Shame and shaming not only deter and punish, but they also may result in some measure of reconciliation and proportionality, as the community itself metes out what it believes is an appropriate punishment for transgression. ${ }^{161}$

Shame and shaming are also cost-effective. Shame costs nothing, since it happens automatically, and shaming, especially in the age of viral Internet discussion, is very inexpensive. Both can be effective even against minor transgressions. Considering the cost of litigation, a lawsuit over an appropriated roller derby pseudonym, an imitated recipe, a stolen joke, or a plagiarized blog post would-even if the law permitted them-surely not be worth the price. In contrast, shame and shaming are virtually free.

For that reason, shame and shaming can level the playing field between Davids and Goliaths. ${ }^{162}$ In many circumstances, intellectual property owners hold all the cards, while accused infringers hold none. It costs very little to send a cease-and-desist letter or to initiate a lawsuit, but resisting that letter or defending that suit can be crushingly expensive and time consuming. ${ }^{63}$ The result is that IP owners may be able to extract monetary settlements or other business concessions without ever giving meaningful consideration to the merits of their claims. In the online context, this effect is particularly powerful. Under the Digital Millennium Copyright Act, protections for alleged infringers are weak, as internet service providers are required to remove accused material even before the alleged infringer has an opportunity to respond to the accusation. ${ }^{164}$ An alleged infringer may have material reinstated by filing a counternotice, but judicial protection for wrongly accused material is not available unless (1) the target of the notice elects to submit a counter-notice; (2) the complainant then

\footnotetext{
160. See supra Part III.A.1.

161. See supra Part III.A.2.

162. See generally Grinvald, supra note 72.

163. See id. at 629-30.

164. Jennifer M. Urban \& Laura Quilter, Efficient Process or "Chilling Effects"? Takedown Notices Under Section 512 of the Digital Millennium Copyright Act, 22 Santa Clara Computer \& High Tесн L.J. 621, 636-37 (2006) (“[A]lleged infringers are subject to removal of their expressive materials, not only before a judge reviews the complaint, but likely even before they receive notice of a complaint. Further, while they have the opportunity to send a counternotice, the material, once removed, must stay down at least 10-14 days according to the statute. The effect may be to substantially burden expressive and other individual rights. In the case of expressive materials, this could be especially significant: ten days to two weeks may greatly diminish the value of the call to a protest, the competitive price, or the newsworthy blog entry." (footnote omitted)).
} 
files suit; and (3) a court resolves the issue. ${ }^{165}$ Shaming gives an inexpensive extralegal option to accused infringers: to shine a bright, public, and critical light on the accuser.

Shaming thus gives IP bullies something to fear. It forces them to examine the quality of their claims because they know that they will be shamed for overreaching and that the consequences of shaming may be far more severe than the benefit they would gain from asserting their rights. In this way, shaming tends to offset other harmful intellectual property phenomena that are not bound by due process, such as the chilling effect of cease-and-desist letters.

Moreover, unlike other penalties, such as fines, shaming can help the shamer directly. Because the shamer is involved in punishing the transgressor, the shamer feels a sense of agency and closure. In fact, when people are "fed up"-for example, as they are fed up with sharp banking practices and white collar crime in the midst of a challenging economy-public shaming may help restore public faith in the shamed industry. If shamed targets take shamers up on their invitations to join a community of values, shamers may begin to regain trust in those targets.

\section{Many Weaknesses}

In analyzing the flaws and risks of shame and shaming as regulatory mechanisms, it is helpful to separate internal shame from external shaming. Each has its own weaknesses.

The chief critique of internal shame is that it is not universal. As discussed above, firms cannot experience shame as individuals do, and while the individuals inside firms may be guided by their own shame or firms may feign shame for reputational reasons, firms as unitary entities are guided by a separate set of principles that may overcome shame. In addition, people who "have no shame" are simply not bounded by the values of their community. In a way, it is very similar to formal law: some proportion of those bound by formal law will decide to disregard it. The difference is that formal law is more reliably enforceable. Shame is enforced principally through shaming-and transgressors who have no shame are less likely to be bothered by shaming. For that reason, shame cannot act as a universal regulatory mechanism.

A subtler, but no less important, critique is that shame is painful. The same thing that makes shame effective also gives it enormous power over those who experience it. Imagine if everyone walked

165. See id. at 628 . 
around wearing a collar that would administer a shock every time one violated a rule of etiquette: it might be very effective at making the world more genteel, but it would not be humane. This is problematic in itself, but it is especially so when one considers that what constitutes shameful behavior is seldom in the discretion of the person experiencing the shame. An outside force-usually some variety of community or family-defines what is shameful. This gives "mob psychology" enormous power to inflict emotional pain on behavioral outliers. ${ }^{166}$ In the broader social context, this may have the severest of consequences, such as the suicides of those who have been socialized to believe that homosexuality is shameful. In the intellectual property context, the consequences may be less severe because the behaviors are less likely to be identity defining,- - one can change one's copying behaviors, but not one's sexuality-but shame is no less powerful in defining people's personal values in the intellectual property context as in any other. The tragic story of Aaron Swartz may serve as a cautionary tale. Swartz, who co-founded the Internet site Reddit and was an outspoken free-information activist, was indicted for downloading 4.8 million academic articles from the JSTOR database with the intent of distributing them for free via peer-to-peer file sharing sites. Swartz committed suicide in January after pleading not guilty. ${ }^{167}$ This highlights the inequality of shame and the variability of its results: Swartz almost certainly experienced a complex set of emotions, including depression and shame, ${ }^{168}$ and he took his own life. JSTOR, which never pursued charges against Swartz, began offering limited free access to its materials in the wake of his death. ${ }^{169}$ The FBI has its own role in this discourse, but it-and the individual prosecutors who pursued Swartz in defense of their own passionately held values-may never feel shame as Swartz did, although some have argued they should. ${ }^{170}$

This highlights a third concern with shame: it requires a static, or at least consistently held, idea of what constitutes good-type and badtype behavior. While this may be common in close-knit communities,

166. See Posner, supra note 3, at 1790-92 (explaining how collective opinion can define goodtype and bad-type behavior).

167. Caroline Bankoff, Reddit Co-Founder and JSTOR Hacker Aaron Swartz Commits Suicide, N.Y. MAg. (Jan. 12, 2013, 12:50 PM), http://nymag.com/daily/intelligencer/2013/01/jstorhacker-aaron-swartz-commits-suicide.html.

168. See Aaron Swartz, Sick, Raw Thought (Nov. 27, 2007), http://www.aaronsw.com/ weblog/verysick.

169. Bankhoff, supra note 167.

170. See, e.g., Lawrence Lessig, Prosecutor as Bully, Lessig Blog, v2 (Jan. 12, 2013) http:// lessig.tumblr.com/post/40347463044/prosecutor-as-bully ("Here is where we need a better sense of justice, and shame. For the outrageousness in this story is not just Aaron. It is also the absurdity of the prosecutor's behavior."). 
it is far from universal on a broader scale. In fact, as the Chick-Fil-A example demonstrates, some may celebrate what others consider shameful. ${ }^{171}$ And even within a given community, there may be dissent about the best approaches to copying and attribution. For the most part, this variability is a benefit because it allows for customization of norms and fine-grained distinctions among and inside communities. Jamband fans can value copying and sharing of live recordings but oppose the copying of commercial releases, ${ }^{172}$ while comedians can disapprove of copying jokes. ${ }^{173}$ Tattoo artists can approve of purchasing and copying "flash" designs, but revile the copying of custom tattoos; they can rely on copyright protection for books of flash, but disapprove of aggressive copyright enforcement. ${ }^{174}$ Fan fiction communities can approve of transformative copying, but disapprove of plagiarism. ${ }^{175}$ But it also means that at the edges of any community, the norms and values may begin to break down. Some roller derby participants have begun registering their names as trademarks, while others place a high value on the sport's self-regulation and would be ashamed to rely on formal law. ${ }^{176}$ Once outliers grab a foothold, values can shift. This flexibility may be good for optimizing norms to match the needs of a given time and community, but it can make shame an unpredictable governing tool. When different people have conflicting views regarding what is shameful, shame is not only incapable of providing predictable governance, but is also guaranteed to govern in a way that some find unacceptable.

External shaming may be even more troublesome as a regulatory mechanism than internal shame. First, shaming only works if someone hears it. If the target never knows that it is being shamed, it will never respond to the shaming; and if no one ever knows that the target is being shamed, there will be no harm to the target's reputation and no lesson imparted to the public regarding what is or should be considered shameful. As the Internet becomes increasingly saturated, it becomes even more difficult for an audience to separate signal from

171. See Satran, supra note 70.

172. See Schultz, supra note 16, at 680.

173. See generally Oliar \& Sprigman, supra note 10.

174. See Perzanowski, supra note 18 , (manuscript at 40-43); see also Beasley, supra note 18, at 1149-50 (describing some tattoo artists' disapproval of a trade organization that undertook aggressive eBay takedowns).

175. See Casey Fiesler, Note, Everything I Need to Know I Learned from Fandom: How Existing Social Norms Can Help Shape the Next Generation of User-Generated Content, 10 VAND. J. ENT. \& TесH. L. 729, 752-54 (2008).

176. Fagundes, supra note 19, at 1129-30, 1137-38. 
noise. This means that the effectiveness of shaming as a regulatory mechanism may end up depending as much on luck as on merit.

In addition, shaming is less effective in communities where identity is plastic. ${ }^{177}$ If the shamed target is anonymous or can easily change identity, the target will not perceive the threat or feel the sting of reputational harm. Many online settings permit or encourage anonymity; in such settings, shaming is largely ineffective. In pseudonymous societies - for example, many online communities-shaming is more effective, but only if pseudonyms are persistent identifiers of a single entity. ${ }^{178}$ Although some of these communities have cultures of reciprocity that most members follow, those members must be guided and governed by their own consciences and internal shame, since there is no mechanism for shaming (or even identifying) those without persistent identities. In those settings, formal remedies-and the subpoena power that accompanies them-are far more effective against those without shame.

Even more problematic is shaming's unpredictability. If the target does not share the values of the shamer, or perceives its actions as justified, the shaming will not generate the shamer's desired reaction. ${ }^{179}$ Most IP owners likely wish to avoid being branded as bullies, but others might actually want to be seen as litigious, "scary" adversaries. ${ }^{180}$ In addition, if the target does not believe that the shamer's values are popular enough to make a meaningful reputational difference, the target can blithely ignore the shamer's efforts. ${ }^{181}$ For this reason, shaming is likely to be ineffective against targets whose market success does not depend on reputation. Shaming-based collective action can be very effective, as it was with the SOPA-PIPA demonstrations that shamed web intermediaries and congresspeople. But the effectiveness of those demonstrations depended largely on the fact that users may have choices about internet service providers and that congresspeople depend entirely on voters. In contrast, shaming cam-

177. See Andrea Vanina Arias, Comment, Life, Liberty, and the Pursuit of Swords and Armor: Regulating the Theft of Virtual Goods, 57 EMORY L.J. 1301, 1340 (2008) (discussing the ineffectiveness of shaming as a remedy for theft of intangible goods in communities where identity is anonymous or ephemeral).

178. See Rothchild, supra note 66, at 967-68 (describing how punishment by shaming and banishment was ineffective in policing the LambdaMOO community when a punished wrongdoer could - and did-immediately rejoin the community post-punishment by using a different pseudonym).

179. See Litowitz, supra note 45, at 55; Rothchild, supra note 66, at 968.

180. See Gallagher, supra note 136, at 494-95 (noting that some rights holders have a strong aversion to publicity surrounding enforcement activities, while others "relish their reputation for being an aggressive IP enforcer").

181. See Maibom, supra note 24, at 569-71; see also Posner \& Rasmusen, supra note 3, at 374. 
paigns against Facebook have been largely ineffective, likely because Facebook perceives no ill effect from violating its customers' norms. ${ }^{182}$ Facebook no doubt knows that its users believe it should be ashamed of its practice of shifting privacy policies with little or no warning, but Facebook also knows that its market power depends on the network effect, not on reputation. ${ }^{183}$ In this way, even the loudest shaming campaign may fall on deaf ears.

Moreover, while shaming campaigns may begin as attempts to integrate an outsider into a community, reintegrative shaming depends on the potential for forgiveness, which may not be forthcoming after a viral shaming campaign. Many members of the Ravelry community continued to revile the USOC long after its public apology. ${ }^{184} \mathrm{~A}$ target looking at the Ravelry example could reasonably ask, "Why bother apologizing, if I will continue to be despised?" The result is that while shaming might spread values to shaming targets through integration or reintegration, it could just as easily lead to recalcitrance, making the target all the more likely to re-offend.

In fact, external shaming can backfire for a number of reasons. While shaming may infuse public opinion with the idea that a particular behavior is "bad," it can have the opposite effect by highlighting how widespread the behavior is. This is particularly likely if campaigns attempt to condemn multiple targets for the behavior before public opinion has condemned it. If a particular type of behavior is a frequent target of shaming campaigns, it could lead targets to believe their behavior puts them in good (or at least numerous) company rather than bad. ${ }^{185}$ For that reason, using shaming to manipulate targets' shame may have unpredictable results: increased formal enforcement may actually undermine norms by signaling that transgression is common or that compliance is "uncool."186 This may be one reason why shaming campaigns have not eradicated peer-to-peer file sharing: those who engage in it may believe that "everyone is doing it."

182. Cf. Posner \& Rasmusen, supra note 3, at 374 ("If the violator . . . anticipates no bad effects on him from the reception of the criticisms by other people, the criticisms will fail as sanctions for the criticized act.").

183. See Morganstern, supra note 67, at 195-97 (discussing mixed effectiveness of collective shaming action in influencing Facebook privacy policies).

184. See, e.g., Memmott, supra note 153 ("Early Reactions to the Apology Aren't Positive").

185. See Litowitz, supra note 45 , at 56.

186. See Posner, supra note 3, at 1791-92, 1804, 1813 (discussing unpredictability of shaming as an enforcement mechanism); see also Steven A. Hetcher, Norm Proselytizers Create a Privacy Entitlement in Cyberspace, 16 Berkeley TeCh. L.J. 877, 879-80 (2001). 
External shaming may also backfire as a result of rage and rebellion. ${ }^{187}$ Although some proportion of shamers may want to integrate (or reintegrate) an offender into a community of norms, their shaming efforts may ultimately push the target away. Viral shaming campaigns lack a central control mechanism and therefore find it difficult to send a consistently integrative or reintegrative message ${ }^{188}$ _and even if they succeed in sending such a message, the target may not hear or appreciate what the shamers have in mind. So unless the target depends heavily on the shamer's community for some reason (e.g., profit), the target can become an "outsider" who will not be interested in integration or reintegration and will not be harmed by ostracism, shunning, or other disintegrative shaming techniques. ${ }^{189}$ Thus, external shaming can create rogues who feel they owe nothing to the community and can therefore transgress with relative impunity. ${ }^{190}$ Indeed, empirical studies associate shaming sanctions that involve stigmatizing the target with higher rates of re-offense. ${ }^{191}$

On the other hand, reactions to shaming can be equally powerful and potentially destructive in the direction of compliance. If the target does share the shamer's values or the audience reacts strongly to the shaming, the results may be extremely damaging or painful. In social science parlance, "either one finds [shaming sanctions] easy to ignore, or one finds them particularly harsh, and cripplingly diminishing of self-esteem. The effectiveness of such sanctions on people of the first sort is nil; with respect to the second sort, the effect is likely to be overkill, and hard to predict." 192 While the former speaks only to shaming's effectiveness, the latter raises what may be a deeper concern: It grants the shamer a potentially overwhelming power to hurt targets and influence values. On one hand, this is powerfully democratizing; entities with very little financial power can shape public opinion effectively through shaming campaigns, as Patent TrollTracker and its ilk have influenced public opinion against patent assertion entities. On the other hand, it can lead to unfair results-especially when shaming is spread virally by a public with incomplete information.

187. See Raffaele Rodogno, supra note 3, at 434 (discussing relationship between humiliation and negative effects in connection with shaming penalties).

188. For example, Ravelry could not exert control over its members' outraged and angry responses.

189. Posner \& Rasmusen, supra note 3, at 380.

190. See McAlinden, supra note 78, at 374 (discussing the disintegrative effects of naming and shaming sex offenders).

191. See Tangney et al., supra note 40, at 709 (discussing studies, including 2007 correlational study of 652 tax evaders).

192. Ullmann-Margalit, supra note 44, at 435 (citations omitted) (internal quotation marks omitted). 
YouTube contains many videos shaming "joke-stealers" whose popularity and careers may be severely injured by the shaming, even if they independently, and thus innocently, invented the same jokes. This can lead to lasting, unearned reputational harm. ${ }^{193}$

This harm occurs without regard for due process or proportionality. It is, in essence, vigilantism. In the words of John Rothchild, "[A] regime of . . . vigilantism is not an entirely attractive prospect." 194 Vigilantism may result in justice, but it is uncontrolled. It is ironic that the shaming campaign to defeat SOPA and PIPA focused largely on highlighting the proposed legislation's creation of an Internet "blacklist" without due process-considering that the campaign essentially blacklisted suspected SOPA and PIPA supporters without any due process. ${ }^{195}$ Blacklisting and watchlisting may be effective shaming techniques, but they can also lead to unsubstantiated "witch-hunting" and disproportionate punishment. ${ }^{196}$

In the intellectual property context, self-policing might mediate this danger. A study of letters submitted to the Chilling Effects database indicated that individuals who had (or believed they had) a strong defense to infringement allegations were more likely to submit their notices to the database. Thus, it appears that the shaming effect of the database is directed at bullies rather than tarring all IP enforcers with the same shaming brush. ${ }^{197}$ But self-policing depends on shared values. When a group of shamers has a variety of views, the least reason-

193. See, e.g., deadfrogcomedy, Judd Apatow vs Denis Leary: Is This Joke Stealing, YouTuBE (July 16, 2008), http://www.youtube.com/watch?v=zUU3Lvs_OxM; deadfrogcomedy, Whose Joke Is It? Carlos Mencia? D.L. Hughley? George Lopez?, YouTube (Feb. 19, 2007), http:// www.youtube.com/watch?v=kPuu_VE7KOA.

194. Rothchild, supra note 66, at 965-66 (describing collateral damage from vigilante overenforcement of spam norms on Internet bulletin boards); see also Whitman, supra note 3, at 1059.

195. See Doctorow, supra note 149 (shaming legislators who supported the bills); see also Gibbs, supra note 149 (shaming websites that did not participate in public demonstration against bills); Wilhelm, supra note 149 (shaming a corporate supporter of the bills).

196. See generally Daniel J. Steinbock, Designating the Dangerous: From Blacklists to Watch Lists, 30 SeAttle U. L. Rev. 65 (2006) (discussing dangers of blacklisting and watchlisting). I understand that by criticizing shaming as a tool for encouraging IP forbearance and preventing overreaching IP assertion, I am postulating a market failure of sorts-arguing that "more information" may not always be better. And to the extent that shaming disseminates accurate information about shaming targets, it is hard to dispute that it may help consumers make informed decisions. That, in itself, would be a benefit of shaming, if it were true. It may not be: the public may over- or undervalue shaming information, and may reach a point of "information overload" when presented with complete information. But even assuming that the consuming public absorbs information perfectly, shaming may generate negative externalities, including disproportionate, unpredictable, or perverse reactions from the shamed targets.

197. See Urban \& Quilter, supra note 164, at 642 (reporting analysis of Chilling Effects submissions). 
able of those views may be the loudest. For example, when the cybervigilante group Anonymous becomes involved in a shaming campaign, reputational harm is only the beginning: the group hacks corporate websites and conducts denial-of-service attacks and other cyber punishments. ${ }^{198}$ The result is that the target cannot retaliate and may not even be able to defend itself. Anonymous's brand of activity may backfire as a method of behavior control; studies show that shaming actually hinders social behavior when it imposes a harsh cost on the transgressor. ${ }^{199}$ But even if it effectively disseminates social values, it imposes the most extreme values and does so at a very high cost.

The upshot of these considerations is that both shame and shaming are problematic as regulatory tools. Of the two, shame may be preferable. Although shame only works on a portion of the population, it is-at least for that portion-both more predictable and more effective than shaming. This is consistent with social science research with computer-simulated societies, which indicates that introducing shame-teaching people to be ashamed of certain anti-social behaviors-"is more effective for the achievement of pro-social behavior than increasing the [shaming-based or other] punishment to non-complying agents." 200

Ultimately, both have benefits and drawbacks. Shame is an excellent mechanism for enforcing norms in relatively close-knit communities of individuals or very small firms. Shaming may currently be the best approach to regulating certain behaviors such as IP bullying and may be particularly helpful in generating a discourse about what behaviors should be considered shameful. But as a replacement for formal law, or even as a mechanism for adjusting the boundaries of formal law, neither shame nor shaming is a panacea.

\section{Normative Implications}

Clearly, neither shame nor shaming should replace formal intellectual property law. They are too unpredictable, risky, and potentially harmful. But it is undeniable, and perhaps beneficial, that they augment and shape the effects of formal law. We can look to current uses of shame and shaming in the intellectual property context to learn

198. See, e.g., Cliff Edwards et al., Sony Caught Up in Cyber War with Indignant Hackers: Company with Security Once Considered 'Robust' Now Dealing with Constant Breaches, Charleston Daily MaIl (May 30, 2011), available at http://www.highbeam.com/doc/1P228794321.html; Internet Strikes Back: Anonymous' Operation Megaupload Explained, RT.com (March 7, 2012, 12:28 PM), http://rt.com/usa/anonymous-barrettbrown-sopa-megaupload-241/.

199. Jaffe, supra note 27 , at 95-96.

200. Id. at 96. 
something about how the public wants intellectual property law to work.

First, we must acknowledge that formal intellectual property laws cannot, and have not, done the job alone. Shame and shaming have always been part of the intellectual property landscape and are increasingly important in moderating the effects of formal protection. This implies that formal law may not be the ideal mechanism for protecting all varieties of intellectual property in all circumstances. In negative-space communities, a lack of formal protection seems to benefit creation and innovation, ${ }^{201}$ at least partly because participants in these communities are governed by customized rule sets enforced by conscience and shame. These communities seem to have little difficulty creating effective systems that meet their own needs. ${ }^{202}$ Some restrict copying; others encourage it with specific provisos such as attribution norms. ${ }^{203}$ The lack of formal protection does not appear to chill creation or innovation; in fact, it seems to encourage it, especially in settings like academia, cuisine, fashion, open-source software, and fandom, where "creative copying,"-building upon the works of others to create something new-advances the creative needs of the community. The norms of these communities are more flexible than formal law, as they are able to change as technology or prevailing markets do. In addition, community members likely follow these norms more assiduously, both because of the power of shame and also because, unlike formal laws made by distant politicians, community members can feel like they had some hand in creating and reinforcing them.

I do not suggest that we should start repealing intellectual property laws because shame will do all the work. However, particularly when considering whether to implement new protections and whether to implement carve-out exceptions to current protections, it is important for lawmakers to consider whether formal enactments will add value beyond shame-based enforcement.

How do we tell the difference between situations where laws are necessary and situations where shame should stand in their place? The discussion above provides some of those answers. Shame cannot be the sole governing mechanism when the transgressors are likely to be firms or other collective entities. But when individuals are the

201. See Rosenblatt, supra note 99, at 348-50; see also Elizabeth L. Rosenblatt, Intellectual Property's Negative Space: Beyond the Utilitarian, 40 FLA. ST. U. L. Rev. 441, 447 (2013).

202. This is consistent with research showing that cooperative (coordination) norms arise organically when they suit collective needs. See Hetcher, supra note 186, at 902-03.

203. See supra Part III.A.1. 
most likely transgressors, then formal law may not be necessary. Second, social science literature indicates that shame and shaming are most effective when reintegrative shaming is possible and when the participants are interdependent on each other. This implies that shame and shaming may do much of the work of formal law in relatively close-knit communities where members are likely to communicate with each other and may depend on each other for creative or inventive purposes. ${ }^{204}$ This includes communities like those discussed above that involve creative copying and countercultures in which belonging to the community and adhering to its values becomes part of the participant's identity, such as sharing or free-information movements, athletics, performance magic, stand-up comedy, or roller derby. Ultimately, the equilibria of low-IP spaces may not be as fragile as one might fear. ${ }^{205}$ In a world of shame, shaming, and interdependence, there are high costs, both emotionally and reputationally, for "going rogue."

While shame and shaming are good at regulating interactions within communities, they are far from ideal for regulating interactions among communities. $^{206}$ As we have seen above, different communities hold different, and often inconsistent, values. Take pro-copying or free-information norms: while these work well within the sharing community, they do not necessarily reflect the needs or values of initial creators. Free-information activists may wish to copy without any respect or understanding for the needs of initial creators, and therefore find no shame in harming them. In that instance, formal law is required. As a more concrete example, many fan fiction writers strongly favor transformative copying, as long as it includes attribution. ${ }^{207}$ They not only write transformative works, but also welcome others to remix (and attribute) their fanworks. ${ }^{208}$ Many commercial authors, however, feel differently. ${ }^{209}$ They may not want the characters they

204. Here, I am referring to communities in which the members are likely to interact with each other.

205. See Dreyfuss, supra note 112.

206. See generally Jeremy A. Schachter, That's My Joke . . Art . . Trick!: How the Internal Norms of IP Communities Are Ineffective Against Extra-Community Misappropriation, $12 \mathrm{VA}$. SPORTS \& EnT. L.J. 63 (2012).

207. See Fiesler, supra note 175 , at $752-54$.

208. See id.

209. In 2012, for example, the estate of Marion Zimmer Bradley sued fan-author Mary Battle, asserting that her works infringed the author's copyrights and trademark rights. Complaint for Copyright and Trademark Infringement at 3-4, Marion Zimmer Bradley Literary Works Trust v. Battle, No. 3:12-cv-00073 (N.D. Cal. Jan. 5, 2012). The same estate contacted the Organization for Transformative Works" "Archive Of Our Own," asserting that noncommercial fan fiction stories posted there infringed Bradley's trademark and copyright rights. See Email from Ann 
invented to be put in new situations, with or without attribution. Because these communities disagree about what constitutes shameful behavior, shame will not adequately govern their interactions, and formal law is necessary to determine whose view "wins" and under what circumstances. For fans and commercial authors, the law does just that: the Copyright Act and its fair use provision provide parameters under which fans can make transformative use of commercial authors' works. ${ }^{210}$ Shame augments formal law to govern fans' behavior among each other (copying is fine, plagiarism is not) and with the commercial authors (showing them fan fiction is generally taboo). Shaming also comes into play, as fans may shame authors or copyright holders who wish to enforce their copyrights against fair uses or attempt to enforce rights they do not have. ${ }^{211}$ This forces rights holders to consider the strength of their claims before asserting them, because a weak claim is more likely than a strong one to generate reputational harm via shaming. ${ }^{212}$ In that setting, therefore, shame and shaming augment law but would not adequately replace it.

While shame and shaming should not be the only mechanisms governing inter-community intellectual property practices, they are still valuable in the inter-community setting, both for governing and for instructing lawmakers about the appropriate boundaries for formal protection. From a governance standpoint, shaming stems the gradual accretion of rights by offsetting the effects of risk aversion and overreaching. Rights holders will inevitably seek to expand protection by asserting rights they do not have or accusing non-infringing activities. Victims of such IP bullying have little formal recourse: they may respond with motions to dismiss, declaratory judgment actions, or antiSLAPP motions, ${ }^{213}$ but doing so requires significant expense and attention, especially considering that bullying victims may have done nothing wrong. In that setting, shifting some of the risk to the bullythe risk of being shamed-may make bullies think twice about over-

Sharp, Tr., Marion Zimmer Bradley Literary Works Trust, to Rebecca L. Tushnet, Professor of Law, Georgetown University Law Center (Sept. 26, 2012) (on file with author).

210. See 17 U.S.C. $\S \S 101,107$ (2006).

211. See, for example, the FreeSherlock campaign waged against the Arthur Conan Doyle Estate's threats against transformative authors, based upon expired copyrights. See FreE SHERLOCK!, http://www.free-sherlock.com (last visited Sept. 24, 2013).

212. See Gallagher, supra note 136, at 495-96 (describing attorney's consideration of norms and shaming in deciding whether to assert rights against fan sites).

213. For a helpful explanation of anti-SLAPP (Strategic Lawsuit Against Public Participation) statutes, see Irina D. Manta, Bearing Down on Trademark Bullies, 22 Fordham Intell. Prop. Media \& EnT. L.J. 853, 862 (2012). 
reaching. ${ }^{214}$ In the creative copying context, for example, this might offset rights holders' coercive power and allow creative copiers the freedom to pursue their art.

From a normative standpoint, shaming demonstrates where the law itself may overreach. When targets are shamed for exercising their own intellectual property rights against plausible opponents-like the shaming of Apple's aggressive patent strategies ${ }^{215}$ or Monster Energy Company's aggressive trademark strategies ${ }^{216}$-it may signal that the problem is not with the rights holder, but with laws so broad that rights holders may use them to make costly and potentially chilling claims. Shaming campaigns identify when formal law ill-serves particular communities and when it has fallen out of line with prevailing social norms and preferences.

The prevalence of shaming in response to overreaching intellectual property assertions may also signal the need to shift power to accused infringers early in the cease-and-desist and litigation processes. As discussed above, under current law, shaming is often the best option for small-scale accused infringers when faced with weak or baseless threats from larger-scale rights holders. ${ }^{217}$ Although shaming creates a workable escape valve for the bullied, it is flawed: shaming campaigns may not reach the desired audience, and if they do, they may backfire in a number of ways. ${ }^{218}$ Even if we are content to leave intracommunity governance to shame, it is risky to leave inter-community governance to shaming. With that in mind, lawmakers may want to consider formalizing other early escape valves for accused infringers,

214. See Armendariz, supra note 143, at 1277-78 (relating a story about how Ford's social media maven Scott Monty responded to shaming by backing away from trademark overenforcement).

215. See, e.g., Henry Blodget, Apple Sues Samsung for 'Slide-to-Unlock' and Other Ludicrous iPhone Patent Violations, BusinessInsider (Feb. 12, 2012, 8:46 PM), http://www.businessinsider. com/apple-sues-samsumg-for-slide-to-unlock-2012-2; Mark Gibbs, Apple's Ridiculous Patent, Forbes (July 27, 2012, 4:45 PM), http://www.forbes.com/sites/markgibbs/2012/07/27/apples-ridiculous-patent/; Ryan Moore, Apple Bullying Samsung Some More [Patent], ANDroid Coliseum (Dec. 29, 2012, 11:21 AM), http://www.androidcoliseum.com/2012/12/apple-bullying-samsungsome-more-patent.html; Aleksi Tzatzev, The 'Magic Glove' and 8 Other Ridiculous Inventions Patented by Apple, Business Insider (Oct. 20, 2012, 11:00 AM), http://www.businessinsider. com/9-of-apples-strangest-patents-2012-10?op=1.

216. See, e.g., \#FightTheMonster, HackettandTiger.com (Aug. 10, 2012), http://hackettandtiger.com/fightthemonster/; Mike Masnick, Monster Energy Drink Hires Trademark Bully To Go After Beverage Review Site, TechDirt (Oct. 19, 2009, 12:15 PM), http://www.techdirt. com/articles/20091019/0420536584.shtml; Nicole Putnam, Monster Energy Company: Stop Trademark Bullying MonsterFishKeepers.com!, CHANGE.ORG, http://www.change.org/petitions/monster-energy-company-stop-trademark-bullying-monsterfishkeepers-com (last visited Sept. 24, 2013) (online petition).

217. See supra Part III.B.1.

218. See supra Part III.B.2. 
such as broader misuse doctrines, causes of action for "baseless threats," or "anti-troll" fee-shifting legislation. ${ }^{219}$ In addition, lawmakers and courts may wish to consider requiring formal apologies as remedies for abuse of process by overreaching plaintiffs. The latter would harness not only the power of shame and shaming, but also the power of plaintiffs' risk aversion. The risk of having to make a public apology might more effectively prevent IP bullying than would the possibility of merely losing a case or having to pay an opponent's fees.

Considering the power of shame and shaming, and the fact that they are already discursively intertwined with intellectual property law, lawmakers may also want to consider the benefits and drawbacks of creating "apology" or "censure" remedies for infringement of formal law. The pros and cons are manifest: formal shaming penalties would signal the shamefulness of intellectual property infringement, and could provide opportunities for reintegration of infringers and emotional vindication for rights holders-but these penalties could backfire and further establish a class of intellectual property "rebels." A full discussion of shaming sanctions as formal remedies for infringement is beyond the scope of this Article, but it should be noted that China's copyright and trademark laws include official censure and apology as punishments for infringement. ${ }^{220}$

In the end, however, examining shame and shaming in the intellectual property context may be most valuable as a tool for determining what people value. Shame and shaming modify formal law to conform to popular conceptions of what the law should be, especially when those conceptions differ from what the law is. Formal law re-

219. The benefits and drawbacks of such approaches are beyond the scope of this Article; I only suggest that, considering their relationship with anti-bully shaming, they are worth considering.

220. See Copyright Law of the People's Republic of China, State Intellectual Property OFFICE, http://english.sipo.gov.cn/laws/relatedlaws/200804/t20080416_380362.html (“Anyone who commits any of the following acts of infringement shall bear civil liability for such remedies as ceasing the infringing act, eliminating the effects of the act, making an apology or paying compensation for damages, depending on the circumstances ....."); see also Anne M. Wall, Intellectual Property Protection in China: Enforcing Trademark Rights, 17 MARQ. Sports L. REv. 341, 362 (2006) (describing Chinese formal copyright remedy of apology, which "brings with it the significant social stigma of shaming," and noting that Chinese courts have increasingly included the apology remedy in orders); Peter K. Yu, From Pirates to Partners: Protecting Intellectual Property in China in the Twenty-First Century, 50 Am. U. L. Rev. 131, 187 n.312 (2000) (describing public shaming as a remedy that may be "unconventional" to the American audience but has the potential to be very effective). As a generalization, however, Chinese culture is thought to be considerably more concerned with reputation and loss of "face" than American culture, and therefore, the threat of official censure may not be as effective a deterrent of behavior in the United States as it is in China. See Heidi Hansen Kalscheur, Note, About "Face": Using Moral Rights to Increase Copyright Enforcement in China, 39 Hastings Const. L.Q. 513, 524 (2012). 
flects the power structure of legislative governance and common law, which rely on influence and compromise to generate rules that may fit poorly in individualized situations. ${ }^{221}$ In contrast, shame and shaming reflect a different power structure: a critical mass of individually powerless people can collectively define and enforce what is shameful, and they can do so in a far more situational, granular manner. Shame and shaming silence the minority, but formal law may compromise away the values of the majority. Neither system reflects the full picture of society, but to ignore shame and shaming is to ignore the will of the people. By examining what is shameful and who is targeted for shaming, one can learn what the critical mass wants from its laws.

The role of shame and shaming in creating and governing negative spaces implies that people gravitate toward "set points" of intellectual property protection. By examining what people find to be shameful, and what they shame others for, we can see that people's collective moral intuition rebels against a complete lack of protection while also resisting a level of protection so high that it chills creation. An examination of shame and shaming also teaches us that the level and details of this optimal set point may not be constant: Some areas of creation may demand a high level of sharing. In others, attribution may be important. In another, even a small amount of copying may be too much.

Considering the power and inevitability of shame, and the unpredictability of shaming, one may conclude that the best outcome would permit shame-based "IP without IP" systems to flourish, while implementing policies that reduce the need for public shaming of those who enforce their intellectual property rights. Regardless of the outcome, however, lawmakers should take note and strive for balance between the "mob justice" of shame and shaming and the one-size-fits all regime of formal law.

\section{Conclusion}

For too long, lawmakers and scholars have ignored the power of shame and shaming to shape intellectual property behavior, as well as their potential to guide the path of formal intellectual property law. Shame and shaming not only reinforce formal law as they do in other areas, but also augment that law. Together, they help to create and maintain intellectual property negative spaces where innovation and creation thrive without significant formal intellectual property protection or enforcement. In areas beyond the reach of formal intellectual property protection, shame helps define the boundaries of informal or

221. See Burk \& Lemley, supra note 131, at 1577 (2003). 
norms-based intellectual property practices. In areas governed by formal intellectual property protection, shaming helps define the boundaries of rights holders' enforcement forbearance.

These effects adjust the boundaries of formal intellectual property protection in a more finely tuned way than formal law can, but they do so at a potentially high cost. Shame is extremely powerful-more so than formal law-but painful, and it is ineffective as a tool for regulating those who do not experience it. Shaming may influence the behavior of more targets, but has notable disadvantages, including not only pain, but also unpredictable results. Despite those flaws, shame and shaming possess marked advantages over formal law for regulating copying behavior. Most notably, shame and shaming are flexible and reflect the needs of the communities they govern, unlike the monolithic, one-size-fits-all dictates of formal law. Shame and shaming are not suitable substitutes for formal law, nor are they miracle cures for law's failings, but they may act as guideposts for determining where to draw the lines of formal legal protection. 
